\title{
Connectivity between seamounts and coastal ecosystems in the Southwestern Indian Ocean
}

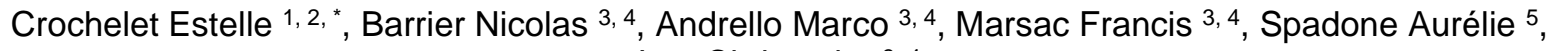 \\ Lett Christophe 3,4
}

${ }^{1}$ ARBRE - Agence de Recherche pour la Biodiversité à la Réunion, 34 avenue de la Grande Ourse, 97434, Saint-Gilles, La Réunion, France

2 IRD / ESPACE-DEV (UMR 228), Parc Technologique Universitaire, 2 rue Joseph Wetzell, CS 41 095,

97495, Sainte Clotilde Cedex, La Réunion, France

3 Institut de Recherche pour le Développement (IRD), Sète, France

4 MARBEC, Univ Montpellier, CNRS, Ifremer, IRD, Sète, France

5 IUCN - International Union for Conservation of Nature, Gland, Switzerland

* Corresponding author : Etelle Crochelet, email address : estelle.crochelet@ird.fr

nicolas.barrier@ird.fr ; marco.andrello@gmail.com ; francis.marsac@ird.fr ; aurelie.spadone@iucn.org ; christophe.lett@ird.fr

\begin{abstract}
:
Understanding larval connectivity patterns is critical for marine spatial planning, particularly for designing marine protected areas and managing fisheries. Patterns of larval dispersal and connectivity can be inferred from numerical transport models at large spatial and temporal scales. We assess model-based connectivity patterns between seamounts of the Southwestern Indian Ocean (SWIO) and the coastal ecosystems of Mauritius, La Réunion, Madagascar, Mozambique and South Africa, with emphasis on three shallow seamounts (La Pérouse [LP], MAD-Ridge [MR] and Walters Shoal [WS]). Using drifter trajectory and a Lagrangian model of ichthyoplankton dispersal, we show that larvae can undertake very long dispersion, with larval distances increasing with pelagic larval duration (PLD). There are three groups of greater connectivity: the region between the eastern coast of Madagascar, Mauritius and La Réunion islands; the seamounts of the South West Indian Ridge; and the pair formed by WS and a nearby unnamed seamount. Connectivity between these three groups is evident only for the longest PLD examined (360 d). Connectivity from seamounts to coastal ecosystems is weak, with a maximum of $2 \%$ of larvae originating from seamounts reaching coastal ecosystems. Local retention at the three focal seamounts (LP, MR and WS) peaks at about $11 \%$ for the shortest PLD considered (15 d) at the most retentive seamount (WS) and decreases sharply with increasing PLD. Information on PLD and age of larvae collected at MR and LP are used to assess their putative origin. These larvae are likely self-recruits but it is also plausible that they immigrate from nearby coastal sites, i.e. the southern coast of Madagascar for MR and the islands of La Réunion and Mauritius for LP.
\end{abstract}

Keywords : Seamounts, connectivity, larval duration, larval drift, Lagrangian modelling, biophysical model, surface drifters, Southwestern Indian Ocean, Ichthyop. 
1. Introduction

52 Marine resources are under threat from the combined effects of climate change, overfishing, pollution, diseases, tourism and coastal development (FAO, 2018). As marine ecosystems degrade, so do the well-being and livelihoods of populations that depend directly on the ecosystem goods and services they provide (Moberg and Folke, 1999). Managing marine resources effectively is therefore crucial, from both social and ecological perspectives. Connectivity is recognized as a key factor affecting marine populations dynamics, population persistence and stock sustainability (Hastings and Botsford, 2006), as well as the efficiency of management strategies in the face of global changes. It is defined as "the exchange of individuals among geographically separated subpopulations" (Cowen et al., 2007). Transport processes are believed to connect distant populations. Despite early genetic studies showing a fair degree of homogeneity between populations over large spatial scales (Doherty et al., 1995), accumulating recent evidence suggests that populations are not as open as initially thought. High levels of local retention and low levels of long-distance dispersal could be maintained by mesoscale and sub-mesoscale eddies capable of transporting larvae back to their location of origin despite long pelagic larval durations (Cowen et al., 2000; Warner and Cowen, 2002), thereby contributing to maintain endemic species around isolated islands (Boehlert et al., 1992).

The majority of marine organisms have a bipartite life history and experience pelagic larval stages before they settle and become sedentary (Leis, 1991). Larvae remain in the midwater layers for days to months while they acquire swimming and sensory capabilities that enable them to control part of their dispersal (Kingsford et al., 2002; Leis, 2002). This pelagic stage facilitates the transport of individuals among spatially isolated populations. It has been suggested that the pelagic larval duration (PLD) is the most important factor determining the 
level of larval dispersal and connectivity (Riginos and Victor, 2001; Selkoe and Toonen, 2011; Luiz et al., 2013). Connectivity between distant populations may indeed be favoured by long PLD, whereas larval settlement close to the natal habitat can result from short PLD and entail increased population differentiation over short scales (Planes et al., 2001). However, larval dispersal is also mediated by both complex and dynamic oceanographic features and biological properties (Pineda et al., 2009).

The effective management of marine resources requires estimating the realized levels of connectivity between populations, but empirical estimates are scarce (Manel et al., 2019). Indeed, marine larvae are notoriously difficult to monitor, due to their small size and possibly long dispersal distances, up to hundreds of kilometers from their initial release site (Leis, 1984; Victor, 1987). Patterns of larval dispersal and connectivity also vary between species. Various methods such as population genetics and phylogeography, microchemical fingerprinting, stable isotopes, otolith microchemistry, otolith shape analysis and biophysical dispersal models have been developed to assess patterns of larvae dispersal and population connectivity across the marine environment (Schultz and Cowen, 1994; Roberts, 1997; Cowen et al., 2000; Hellberg, 2007; Treml et al., 2008; Jones et al., 2009; Mora et al., 2012, Bryan-Brown et al., 2018).

The South West Indian Ocean (SWIO) has a high level of marine biodiversity, and marine species in the region are widely used as food resources and provide economic benefits to a rapidly growing human population. However, the SWIO is one of the less studied regions of the world (Obura, 2012; UNEP-Nairobi Convention and WIOMSA, 2015). 
The SWIO has many seamounts. Seamount ecosystems are recognized as critical habitats for

101 a wide array of species (Clark et al., 2012) and are subject to anthropogenic exploitation

102 (Rowden et al., 2010). Despite an increased focus on these particular ecosystems, the natural

103 processes involved to sustain biodiversity at seamounts remain largely unknown, in particular

104 in the SWIO. Seamounts are generally geographically isolated structures, but currents can

105 ensure connectivity between them and with adjacent ecosystems.

106

107 In this paper, we consider nine seamounts of the SWIO, ranging from latitudes $15^{\circ} \mathrm{S}$ to $45^{\circ} \mathrm{S}$

108 (Figure 1), which were the focus of previous oceanographic campaigns (Southern Indian

109 Ocean Seamounts Project in 2009: Read and Pollard, 2017; Rogers et al., 2017; Pollard and

110 Read, 2017). Five of them belong to the South West Indian Ridge (SWIR, 25-50 ), an area

111 delineated by elevated rims reaching up to $2000 \mathrm{~m}$ below sea level, with several seamounts on

112 its flanks rising to only a few hundred metres below the surface (Guinotte, 2011): Atlantis

113 Bank, Sapmer Bank, Middle of What Seamount, Melville Bank and Coral Seamount. The

114 SWIR is crossed by subtropical and Agulhas Return Current convergences (Figure 1). These

115 strong hydrological discontinuities are almost impassable by small size organisms, both in the

116 adult and larval stages. There is therefore no genetic connectivity between populations north

117 and south of the subtropical convergence line (Rogers, 2012). We include three other

118 seamounts located on the Madagascar Ridge: two unnamed pinnacles - hereafter called

119 MAD-Ridge and Un-named seamount respectively) and Walters Shoal. The rugged

120 topography and numerous shoals on this portion of the Madagascar Ridge interact with ocean

121 currents (Roberts et al., 2020, this issue; Vianello et al., 2020, this issue). MAD-Ridge is a

122 steep pinnacle (33 km north-south; $22 \mathrm{~km}$ east-west) located $240 \mathrm{~km}$ south of Madagascar

123 and rises to $240 \mathrm{~m}$ below the surface. It is under the influence of a highly dynamic ocean

124 circulation (the East Madagascar Current and its retroflection, Figure 1; de Ruijter et al., 
2004) inducing strong mesoscale activity (Pollard and Read, 2017; Vianello et al., 2020, this

126 issue). Indeed, it is frequently crossed by mesoscale eddies spinning off the South East Madagascar Current. These eddies may become trapped over the seamount and have an influence on the assemblages and diel vertical migrations patterns of micronekton communities (Annasawmy et al., 2020, this issue). Walters Shoal and Un-named seamount are very isolated features $(>800 \mathrm{~km}$ south of Madagascar, $1300 \mathrm{~km}$ off the South African coastline) located at the southern end of the Madagascar Ridge. Both seamounts are classified as Benthic Protected Areas by the Southern Indian Ocean Fisheries Agreement (Shotton, 2006; SIOFA, 2019). Walters Shoal is a large seamount rising to $18 \mathrm{~m}$ below the surface located $855 \mathrm{~km}$ south of Madagascar. Previous investigation showed a $400 \mathrm{~km}^{2}$ caldera-like shape of the summit (RV Marion Dufresne cruises in 1973 and 1976, unpublished data). It has moderate mesoscale dynamics (Pollard and Read, 2017). The last seamount considered, La Pérouse, is located $160 \mathrm{~km}$ northwest of La Réunion Island. It is under the influence of the west-flowing South Equatorial Current (SEC, Figure 1) (Tomczak and Godfrey, 2003; Chapman et al., 2003) and has moderate mesoscale dynamics. As an old volcano, La Pérouse rises steeply to 55-60 m depth from the abyssal plain at $5000 \mathrm{~m}$ and is $10 \mathrm{~km}$ long (Marsac et al., 2020, this issue).

We also considered eight coastal sites, where knowledge on species and/or circulation were available, to assess exchanges with the seamounts: (i) two Mascarene archipelago sites, the west coast of Mauritius (Morne Brabant) and La Réunion (La Saline); (ii) four sites in Madagascar (Sainte-Marie and Mamanjary on the east coast, Fort-Dauphin in the south and Tulear in the southwest); and (iii) two sites on the African coast (Tofo in Mozambique and Saint Lucia in South Africa) (Figure 1). As these coastal sites are not fully representative of the respective coastlines, we also defined buffers around countries (Mauritius, La Réunion, 
Madagascar, Mozambique and South Africa), $1 / 3^{\circ}$ from shore, to highlight larval export from

151 seamounts to surrounding countries.

152

153 The aim of this paper is to assess the degree of connectivity, deduced from hydrodynamic

154 larvae dispersion, between the nine selected SWIO seamounts and nearby coastal ecosystems

155 represented by the eight coastal sites and also nearby countries. Emphasis is placed on the

156 three shallow seamounts which are the focus of the present Special Issue: La Pérouse (LP -

157 doi:10.17600/16004500), MAD-Ridge (MR - doi:10.17600/16004900) and Walters Shoal

158 (WS - doi: 10.17600/17002700) (Roberts et al., 2020, this issue). In order to characterize

159 connectivity patterns, we first used drifter trajectory data as evidence for possible

160 hydrodynamic connectivity. Then, to gain a broader view of connectivity patterns, we used

161 Ichthyop, a Lagrangian model (Lett et al., 2008) to simulate ichthyoplankton dispersal. This

162 model was forced by near-surface ocean current estimates (OSCAR). A wide range of PLD

163 values were considered to provide a synoptic view of seamount connectivity. Finally, we used

164 information on PLD and the age of larvae collected at MR and LP by Harris et al. (2020, this

165 issue) to assess their putative origin.

166

167 2. Material and methods

168 2.1 SWIO marine species

169 More than 800 fish species have been recorded on seamounts worldwide (Morato et al.,

170 2004). Most are robust demersal fish species, with good swimming capabilities, high food

171 consumption and energy expenditure. Some of them also exhibit great longevity (over 100

172 years) with late maturation (50-60 years) and low fertility, making them extremely vulnerable

173 to intensive fishing (Koslow et al., 2000).

174 
175 Soviet and Ukrainian fisheries operating from 1969 to 1998 in the SWIO identified 81 fish

176 families including four Beryx species (alfonsinos, including Beryx splendens and $B$.

177 decadactylus) and orange roughy (Hoplostethus atlanticus) of high commercial value, pelagic

178 pentacerotidae (Pseudopentaceros wheeleri, P. richardsoni), rockfish (Sebastes spp.,

179 Helicolenus spp.), oreos (Oreosomatidae), cardinal fish (Epigonus spp.), grenadiers (including

180 Coryphaenoides rupestris) and Patagonian toothfish (Dissostichus eleginoides) (Romanov,

181 2003). These fish are specifically associated with seamounts, although they also live on the

182 continental slopes and slopes of oceanic islands. Soviet and Ukrainian fisheries also

183 inventoried a minimum of 13 threatened species of shark (Romanov, 2003) and benthic

184 resources such as crustaceans (lobsters, crabs), molluscs, sponges, and cold-water corals. A

185 new species of spiny lobster, Palinurus barbarae (Groeneveld et al., 2006), appears to be

186 endemic to the Walters Shoal (WS), as well as the crab Beuroisia duhameli (Guinot and

187 Richer de Forges, 1981) caught during the MD08 campaign of RV Marion-Dufresne in 1976.

188 More recently, cruises to La Pérouse (LP), MAD-Ridge (MR) and the WS seamounts allowed

189 identification of several micronekton species. Annasawmy et al. (2019) reported vertically

190 migrating common open-water species of gelatinous crustaceans, squid and fish concentrated

191 over the summit and flanks, and also an important community of seamount-

192 associated/resident fish. Harris et al. (2020, this issue) also collected mesopelagic fish larvae

193 during the current cruises, Myctophidae and Gonostomatidae being the most dominant

194 families at all three seamounts.

196 Despite these valuable recent data, biological data on marine species inhabiting SWIO

197 seamounts are generally lacking, as underlined in several publications (Rogers, 2012; FFEM,

198 2013; Rogers et al., 2017; Zucchi et al., 2018). In particular, there is only limited information

199 available on their PLD for ichthyological species recorded during sea campaigns (e.g. 
Pseudopentaceros richardsoni, Hoplostethus atlanticus, Beryx splendens), which have PLDs

201 ranging from one to several months. Hence, Beryx spp. may have a PLD of around one year 202 (Shotton, 2016). Jasus spp. (spiny lobsters) were recorded in seamount habitats in the

203 southern hemisphere and are also known to have long PLDs. Hence, Booth (2006) reported 204 PLDs between 8 and 12 months for $J$. verreauxi, and between 12 and 24 months for $J$. 205 edwardsii. Harris et al. (2020, this issue) provided information on specimens collected at MR 206 of the acanthurid Naso sp. having a PLD of 84 d, Labrid spp. with a PLD of 26-28 d, Apogon 207 spp. with a PLD of 18-34 d and Synodus sp. with a PLD of $42 \mathrm{~d}$ (Stier et al., 2014). Thus, the 208 different species inhabiting the SWIO seamounts cover a large range of PLD values.

\subsection{Oceanographic drifter trajectories}

211 As a first approach to assessing dispersal and connectivity in the SWIO, we downloaded 6-h interpolated trajectories of 1104 drogued oceanographic surface drifters located in the SWIO over the period $15 / 02 / 1979$ to $30 / 06 / 2018$ from the Global Drifter Program database

214 (https://data.nodc.noaa.gov/cgi-bin/iso?id=gov.noaa.nodc:AOML-GDP, Lumpkin and 215 Centurioni, 2019). From that dataset, we selected drifters that came close ( $<50$ or $100 \mathrm{~km})$ to 216 one of the three focus seamounts (LP, MR and WS) and plotted their trajectories. We also searched for drifters that came close to two of the same seamounts, as an indication of 218 possible hydrodynamic connectivity between seamounts.

\subsection{Ichthyop larval dispersal model}

221 To gain a broader perspective of dispersal and connectivity in the SWIO, we used the larval 222 dispersal tool Ichthyop, a free Lagrangian tool designed to study the effects of physical and 223 biological factors on ichthyoplankton dynamics (Lett et al., 2008). Ichthyop can integrate the 224 most important processes involved in the early life stages of marine larvae: spawning, 
transport, behaviour, growth, mortality and settlement. As we wished to obtain a synoptic view of connectivity patterns, rather than focus on a particular species, we used a large range of PLD values $(15,30,45,60,90,120,180,270$ and $360 \mathrm{~d})$ and assumed that all seamounts had habitats and populations capable of both producing and receiving larvae. This latter assumption is supported by the findings of Harris et al. (2020, this issue) who reported all developmental stages of oceanic and some neritic taxa from preflexion to postflexion at LP, MR and WS, an indication that the corresponding species spawn in the vicinity of these seamounts. We also assumed that larvae were transported passively depending only on horizontal surface currents. The term "larvae" used in the modelling part of this paper really stands for "virtual larvae" because there were no ground truth data to calibrate and validate the model. Particles were released every 5 d over 9 years, i.e. 10000 particles at each of the considered release locations, a number that was shown to be large enough to provide precise estimates of connectivity values (Andrello et al., 2013). Release locations (Figure 1) were the nine SWIO seamounts and the eight coastal sites described in the introduction. Potential larval destination areas were the nine SWIO seamounts, the eight coastal sites and the shorelines of

240 the five countries (Mauritius, La Réunion, Madagascar, Mozambique and South Africa;

241 Figure 1). Simulations were performed with two sizes of buffer around locations used as release and destination areas, $1 / 3$ of a degree and 1 degree.

244 As expected, the simulated values of connectivity were overall greater with a $1^{\circ}$ buffer than 245 with a $1 / 3^{\circ}$ buffer, but as the connectivity patterns (i.e. sites that are more/less retentive, 246 more/less connected, etc.) were similar, we only present the $1 / 3^{\circ}$ case and refer the reader to 247 Appendix Figure $\mathrm{E}$ for the $1^{\circ}$ buffer results. The Ichthyop model was forced by current fields 248 provided by the OSCAR product (see below) interpolated linearly at the location and time of 
each larva, and their movement was solved using the Runge Kutta $4^{\text {th }}$ order scheme, diffusion being added with a dissipation rate $\varepsilon=1 \mathrm{E}^{-9} \mathrm{~m}^{2} \mathrm{~s}^{-3}$ (following Peliz et al., 2007).

\subsection{OSCAR current product}

OSCAR (Ocean Surface Current Analyses - Real Time) provides estimates of ocean nearsurface currents by combining satellite-derived altimetry observations (sea-surface height; e.g. TOPEX/Poseidon), scatterometer data that estimate ocean wind vectors, and sea surface temperature sensors (e.g. AVHRR). OSCAR provides more precise ocean current estimates than those based exclusively on altimetry, particularly in the tropics, by combining geostrophic shear dynamics, Ekman and Stommel transport and a complementary term of surface buoyancy gradient (Bonjean and Lagerloef, 2002). Products are available worldwide at $1 / 3^{\circ}$ horizontal resolution every $5 \mathrm{~d}$ and represent currents at a depth of $\sim 15 \mathrm{~m}$. Here we used the currents data for the SWIO (latitude $10-50^{\circ} \mathrm{S}$, longitude $20-70^{\circ} \mathrm{E}$ ) over the period 2010-2018, downloaded from the NASA data center website (ftp://podaacftp.jpl.nasa.gov/allData/oscar/preview/L4/oscar_third_deg/). OSCAR products were validated

264 for the northern part of the Indian Ocean by Sikhakolli et al. (2013).

\subsection{Model outputs and post-processing}

267 We calculated connectivity matrices between seamounts, between seamounts and coastal 268 ecosystems, and between coastal ecosystems and seamounts for all the considered PLD values

269 averaged over all release dates. Connectivity can be interpreted as either the proportion of 270 larvae exported to each seamount or coastal ecosystem (larval export, lines of the connectivity 271 matrices), or the proportion of larvae coming from each seamount or coastal ecosystem (larval 272 import, columns of the connectivity matrices). Local retention, i.e. the proportion of released 273 larvae that stayed at their natal sites, is the diagonal of the connectivity matrices. We also 
274 computed the dispersal distance as the "great-circle distance" between the initial and final

275 positions of larvae, averaged for all larvae and release dates. We plotted maps of simulated

276 larval density, the average number of all larvae per cell at a given time. The cell size was set

277 as $1 / 3^{\circ}$, equivalent to the OSCAR resolution. Analyses were carried out using the software

278 ArGIS 10.4.1 and Spyder (Python 2.7).

279

\section{3. Results}

\subsection{Drifters}

We found 13, 11, and 14 drifters passing less than $<50 \mathrm{~km}$ from the LP, MR and WS seamounts, respectively, at some time in their travel in the SWIO (Figure 2). Most (11/13) drifters that came close to LP ended up to the south in the direction of the other seamounts (Figure 2a). One drifter (\#45958) that came very close to LP ( $7 \mathrm{~km})$ was also close to MR

Figure 2a). Drifters that travelled close to MR moved to the west or to the east and none travelled to LP or WS (Figure 2b). Most (10/14) drifters that came close to WS ended up to the west (Figure 2c), but along the way one drifter (\#63941330) came close ( $43 \mathrm{~km})$ to $\mathrm{MR}$ after $75 \mathrm{~d}$ (the trajectory of that drifter is highlighted by a white background in Figure 2c).

We found 32, 23 and 21 drifters that travelled $<100 \mathrm{~km}$ from LP, MR and WS, respectively

294 (Appendix Figure A). Among those, six drifters came close to LP and then MR (with 46-189 $295 \mathrm{~d}$ spent in between), two drifters travelled close to MR and then WS (29 and $70 \mathrm{~d}$ spent in between) and two drifters came close to WS and then MR (75 and $143 \mathrm{~d}$ spent in between).

297 One of those drifters (\#9108691) is of particular interest because it came close to first LP ( 51 $298 \mathrm{~km})$, then MR $(\sim 71 \mathrm{~km})$ and finally WS $(\sim 18 \mathrm{~km})$, and was the fastest drifter, travelling from 
LP to MR in $46 \mathrm{~d}$ and from MR to WS in $29 \mathrm{~d}$ (the trajectory of that drifter is highlighted by a

300 white background in Appendix Figure A).

\subsection{Mean dispersal distances}

303

In the simulations, as expected, the mean dispersal distances travelled by the virtual larvae leaving seamounts increased with PLD, ranging from $217 \mathrm{~km}$ for PLD = $15 \mathrm{~d}$ to $1366 \mathrm{~km}$ for PLD = $360 \mathrm{~d}$, all seamounts averaged (Table 1). Larvae leaving Atlantis Bank had the shortest average dispersal distances (around 0.6 times less than the mean) except for PLD $=15$, where the shortest distance was for larvae leaving WS (Table 1). Conversely, larvae from Coral Seamount had the highest mean dispersal distances for all PLD (1.5-2.15 times above the mean). For the three focal seamounts, larvae released from WS travelled the shortest average distances, whereas larvae leaving MR travelled farthest.

\subsection{Connectivity matrices between all sites}

Matrices presented in Figure 3 show the mean simulated larval connectivity obtained between all nine seamounts and eight coastal sites for three of the considered PLD values: 15, 120 and $360 \mathrm{~d}$ (matrices for the six other PLD values are provided in Appendix Figure B). For a PLD of $15 \mathrm{~d}$ (Figure 3a), there were bilateral exchanges between Morne Brabant (Mauritius coastal site), La Saline (La Réunion coastal site) and LP, one of our three focal seamounts. For the other two seamounts, there was also bilateral exchange between WS and Un-named Seamount (which are close) and between MR and Fort Dauphin. The highest local retention values were for WS (11.1\%), Atlantis Bank (7.5\%) and LP (5.3\%), in decreasing order. For a PLD of 120 $\mathrm{d}$ (Figure 3b), there was bilateral connectivity between the five sites situated East of Madagascar (Maurice, La Réunion, LP, Mamanjary, Ile Ste Marie) and most of the seven sites located south of Madagascar and in the Mozambique Channel (WS, Un-named Seamount, 
324 MR, Fort Dauphin, Tulear, Tofo, Saint Lucia). Finally, there was connectivity between most

325 of the five seamounts situated on the SWIR (Atlantis Bank, Sapmer Bank, Middle of What

326 Seamount, Melville Bank, Coral Seamount), attaining an elevated degree between Sapmer

327 Bank, Middle of What seamount and Melville Bank. There was also bilateral exchange 328 between WS and MR, LP and MR, and WS and LP. For a PLD of $360 \mathrm{~d}$ (Figure 3c), most 329 sites were connected in both directions to some extent: the SWIR and South Madagascar 330 seamounts group tended to join. WS, MR and LP were connected bilaterally to all seamounts 331 and coastal sites, with the sole exception of LP which did not receive any larva from Saint 332 Lucia. We assessed the temporal variability (seasonal and interannual combined) of simulated 333 connectivity for the different PLD values (Appendix Figure C) and obtained little variability 334 with coefficients of variation (CV) of 2.7 at most. The CV tended to decrease with PLD, and 335 to have similar values for seamounts within the three different identified groups, i.e. east 336 Madagascar, south Madagascar and Mozambique Channel, and SWIR, and also between two 337 different groups (hence the "blocks" of similar colours in Appendix Figure Cc).

\subsection{Connectivity matrices between LP, MR and WS seamounts and coastal ecosystems}

340 Figure 4 represents exchanges from seamounts to coastal ecosystems (coastal buffers) for 341 PLD values of 15, 120 and $360 \mathrm{~d}$ (matrices for the six other PLD values are in Appendix 342 Figure D).

343 After $15 \mathrm{~d}$ of dispersal, connectivity ranged from 0 to $2.1 \%$. Larvae released at LP reached the 344 coastal ecosystems of Mauritius (0.007\%), Madagascar (0.03\%) and La Réunion (2.1\%), 345 whereas larvae from MR only reached Madagascar. After $120 \mathrm{~d}$, larval connectivity values 346 were divided by $\sim 5$, ranging between 0 and $0.42 \%$. Larvae from LP reached all coastal 347 ecosystems (Mauritius, La Réunion, Madagascar, Mozambique and South Africa). The two 348 highest connectivity values were between LP and Madagascar (0.42\%) and between LP and 
La Réunion (0.21\%). Larvae from MR also reached all coastal ecosystems, but with lower

350 connectivity values. Larvae from WS reached all coastal ecosystems except Mauritius, with

351 even lower connectivity values. After $360 \mathrm{~d}$ of dispersal, larval connectivity values were

352 divided by $\sim 10$ relative to PLD $=120$ d. All larvae leaving LP, MR and WS reached all

353 coastal ecosystems. Overall, the lowest connectivity was from WS, except to Mozambique

354 where it was the highest.

\subsection{Larval dispersal from $L P, M R$ and $W S$}

357 The patterns of weak connectivity between seamounts and the coast described above result 358 from a high degree of dispersal towards offshore locations, as shown by maps of larval 359 density over the entire region. Figure 5 presents mean larval density maps for larvae released 360 at LP, MR and WS seamounts after 15, 120 and $360 \mathrm{~d}$ of PLD (with the locations of the 361 drifters of Figure 2 superimposed). Larvae released from LP remained concentrated at high 362 density on the eastern side of Madagascar for a PLD of up to $120 \mathrm{~d}$, and then tended to drift 363 east. After 120 d, larvae released at MR split into two separate plumes, one directed east and 364 the other west towards the South African coast. Larvae released at WS remained concentrated 365 around that seamount for a longer time, eventually spreading east and west, similarly to larvae 366 released at MR.

\subsection{Local retention and connectivity between $L P, M R$, and WS}

369 Local retention decreased with increasing PLD for all three seamounts, but at a faster rate for

370 LP than for MR and WS (Figure 6). Conversely, connectivity between pairs of seamounts 371 initially increased with increasing PLD values (Figure 7). Patterns of connectivity change 372 with PLD and were similar for MR to WS, MR to LP, and WS to MR, first increasing 373 strongly, then peaking around $120 \mathrm{~d}$ and eventually decreasing slightly for longer PLDs. 
374 Connectivity between the most distant sites, WS and LP, was much weaker and continued to

375 increase with PLD in the range of values tested. Connectivity from LP to MR was at an 376 intermediate level and showed the least change with PLD.

\subsection{Larval import at LP, MR and WS}

379 The origin of larvae reaching LP, MR and WS is shown in Figure 8 after PLDs of 15, 120, 380 and 360 d. At 15 d, larvae reaching WS, MR and LP were mostly self-recruits $(95 \%, 95 \%$ and $38177 \%$, respectively). For a PLD of $120 \mathrm{~d}$, there was still a lot of self-recruitment at WS (42\%) 382 and MR (38\%), but not at LP (15\%), at which 57\% of larvae came from Madagascar. At 360 383 d, there was still $27 \%$ of self-recruitment on WS and no larvae coming from LP. The pattern 384 was similar for MR, but with only $17 \%$ of self-recruitment. For LP, there was only $9 \%$ of self385 recruitment, with the balance of larvae originating from MR (15\%), WS (2\%), Mauritius and La Réunion (20\%), Madagascar (37\%) and other seamounts (10\%).

\subsection{Link with ichthyoplankton data}

389 It is difficult to interpret the above results in a biological sense because the larval durations of

390 the species inhabiting the seamounts are poorly known. However, Harris et al. (2020, this 391 issue) provide useful information on PLD and age for a set of larvae they collected at MR and 392 LP. In particular, at MR, they collected larvae of four species with estimated PLDs close to 30 $393 \mathrm{~d}$ (Labrid and Apogon spp.), $45 \mathrm{~d}$ (Synodus sp.) and $90 \mathrm{~d}$ (the acanthurid Naso sp.). Assuming 394 that these species reproduce at all the sites under consideration, dispersal patterns can be 395 obtained for these PLD values (Figure 9) and also larval import and export for MR, where 396 most larvae were collected (Figure 10). For a PLD of 30 d, virtual larvae arriving at MR 397 originated from Fort Dauphin, MR and Un-named seamount (Figure 10). For a PLD of 45 d, 
virtual larvae arriving at MR originated from Saint Lucia, Tofo, Fort Dauphin, MR, Unnamed seamount and WS. For a PLD of $90 \mathrm{~d}$, they originated from all 17 release sites.

Harris et al. (2020, this issue) also provide age estimates for some of the larvae they collected. All larvae collected at MR were in the range 1.4-16.2 d, a range is largely consistent with the ages of virtual larvae transported from Fort Dauphin to MR in our simulations (Figure 11a). Ages of virtual larvae transported from Mamanjary to MR (>10 d, Figure 11b) suggest that the oldest larvae collected, such as Synodus and Trachinocephalus myops, may also have been transported from there. At LP, all larvae collected except one (a macrourid species) have estimated ages $>5 \mathrm{~d}$ and may therefore have been transported from La Saline (Figure 11c), whereas collected larvae $>10$ d (Vinciguerria spp.) may also have come from Morne Brabant (Figure 11d). Of course, all larvae collected could also have been self-recruits.

\section{Discussion and perspectives}

412 The aim of this work was to assess the degree of connectivity between nine seamounts of the 413 South West Indian Ocean (SWIO) and nearby coastal ecosystems, with emphasis on three 414 shallow seamounts: La Pérouse (LP), MAD-Ridge (MR) and Walters Shoal (WS). The 415 Lagrangian model of larval dispersal allowed us to explore a wide range of pelagic larval 416 durations (PLDs) and revealed robust patterns of larval connectivity.

\subsection{Mean drift velocities and larval dispersal distance}

419 Larvae dispersed far from their site of origin, with travelled distances increasing with PLD.

420 Mean drift velocities, obtained by dividing the mean larval distances reported in Table 1 by 421 PLD, reached values as high as $10 \mathrm{~km} \mathrm{~d}^{-1}$ (about $0.1 \mathrm{~m} \mathrm{~s}^{-1}$ ). Such values are consistent with 422 current surface velocities found by Pollard and Read (2017) and Vianello et al. (2020, this 
423 issue) during the MAD-Ridge cruise. They are also of the same order of magnitude as other

424 estimates obtained by Lagrangian simulations in other regions. For example, median drift

425 velocities were about $4 \mathrm{~km} \mathrm{~d}^{-1}$ in the Mediterranean Sea (Andrello et al., 2013). Other

426 connectivity studies performed in the SWIO have highlighted long-distance colonization,

427 possibly over several generations, between coral reefs (Crochelet et al., 2016), between South

428 African ecosystems and La Réunion for vagrant dusky groupers (Reid et al., 2016), between

429 Mauritius and La Réunion for honeycomb groupers (Crochelet et al., 2013), between the

430 Mascarene archipelago and Madagascar for tropical eel (Pous et al., 2010) and Seychelles for

431 Sargassum algae (Mattio et al., 2013), between the east African coast and Madagascar for 432 mangrove propagules (Van der Stocken and Menemenlis, 2017) and for coral reef species 433 (Gamoyo et al., 2019; Schleyer et al., 2019), and between ABNJ (Areas Beyond National 434 Jurisdiction) and coastal zones (Popova et al., 2019, Maina et al., 2020). Our results focusing 435 on seamounts show that currents around SWIO seamounts can be powerful means of larval 436 dispersal over relatively long distances. The longest dispersal distances were obtained from 437 the Coral Seamount, the southernmost seamount considered in this study, which is affected by 438 the strong current velocities of the Agulhas Return Current.

4.2 Potential colonization of coastal sites by larvae originating from seamounts

441 Connectivity from seamounts to coastal ecosystems was weak, with a maximum of $2.1 \%$ 442 larvae originating from seamounts reaching coastal ecosystems. It is difficult to conclude 443 whether such a low percentage of dispersal is good enough to influence the communities of 444 the receiving sites, because the magnitude of immigration depends on survival during the 445 pelagic phase and on local dynamics (Armsworth, 2002; Burgess et al., 2014). If a population 446 is not self-sustaining as a consequence of high mortality or low fecundity rates, then 447 immigration from other populations contributes to population persistence. Although some of 
448 the seamounts mentioned herein are subject to fishing (with strong impacts on stocks of long-

449 living species), coastal ecosystems are affected by greater anthropogenic pressure (e.g.

450 fishing, dredging, pollution) and generally have smaller biomasses than isolated sites (Edgar

451 et al., 2014; Cinner et al., 2016). Therefore, seamounts could be important sources of larvae

452 for coastal sites, if connectivity is strong enough to transport sufficiently high numbers of

453 larvae over long oceanic distances and the receiving habitat is appropriate. Owing to the lack

454 of data on local population dynamics and abundance in both the seamounts of origin and the

455 coastal sites of destination, however, this hypothesis cannot be tested here.

\subsection{Local retention at seamounts and connectivity between seamounts}

458 Local retention (within a $1 / 3^{\circ}$ buffer) at the three focal seamounts (LP, MR and WS) was also 459 low, peaking at about $11.1 \%$ at the shortest PLD and decreasing sharply at longer PLDs. 460 These values may be an underestimation of actual patterns of local retention, however, 461 because of the relatively coarse spatial resolution of the ocean current product (OSCAR) and, 462 perhaps more importantly, the assumption of passive larval dispersal, because active 463 swimming and larval orientation mechanisms can increase local retention (Faillettaz et al., 464 2018). Even if retention probabilities seem low, though, they might be sufficiently high to 465 replenish populations and ensure their persistence because of high fecundities of the fish species. For example, large female alfonsino (Beryx splendens) spawn a range of 0.8-2.4 467 million eggs (Alekseeva, 1983). We also found that local retention was greater at WS than at 468 MR (Figure 6), which is consistent with Vianello et al. (2020, this issue) showing that 469 currents decrease from north to south along a transect going from MR to WS.

471 Maina et al. (2020) recently used a modelling approach similar to the one used here to assess 472 connectivity between seamounts of the SWIO using a PLD of 30 d. Here, we used a range of 
473 PLD values from 15 to $360 \mathrm{~d}$ and showed that connectivity patterns change dramatically with

474 PLD. Here we obtained large differences in dispersal and connectivity patterns for PLD

475 values of 30, 45 and 90 d, which correspond broadly to labrid and Apogon spp., Synodus sp.,

476 and acanthurid Naso sp., respectively, collected by Harris et al. (2020, this issue) at MR

477 (Figure 10). Therefore, differences in the putative origin of these collected larvae were 478 significant (Figure 9), although a local (i.e. MR) origin was the most likely for all of them.

479 For some species, the presence of larvae, juveniles and adults around the same seamount 480 suggests that their populations are self-sustaining (Cherel et al., 2020, this issue). For neritic 481 reef-associated species, it is also plausible that some of the larvae collected at MR originated 482 from the south-east coast of Madagascar (Harris et al., 2020, this issue). Indeed, MR has a 483 strong connection with the shelf waters through cross-shelf transport. This suggestion is 484 supported by our age analysis of larvae, which shows that larvae arriving at MR may come 485 from Fort Dauphin or Mamanjary (Figure 11). Similarly, it is also possible that larvae 486 collected at LP come from the islands of La Réunion and Mauritius (Figure 11).

Connectivity patterns between seamounts revealed three groups of greater connectivity: the region between the eastern coast of Madagascar, Mauritius and La Réunion islands; the seamounts of the SWIR; and the pair Walters Shoal - Un-named seamount. Connectivity 491 between these three groups was only at long PLDs.

493 With the exception of the two lowest connectivity values (between WS and LP), connectivity 494 peaked at around $120 \mathrm{~d}$ PLD and remained stable or slightly decreased at longer PLDs (Figure 495 7). However, that pattern does not consider the effects of larval mortality, which are likely to 496 reduce connectivity proportionally to PLD. 
We found little temporal variability in simulated connectivity patterns, which is consistent with Vianello et al. (2020, this issue) who reported no clear seasonality or interannual variability in currents along the Madagascar Ridge.

\subsection{Complementarity of drifter data and Lagrangian simulations}

503 Drifter data were used as ground-truth information of hydrodynamic dispersal and 504 connectivity, and they consolidated the results of Lagrangian modelling. Indeed, the trajectories followed by drifters passing close to each of the three focal seamounts were consistent with the general patterns followed by particles released there. In addition, we found drifters passing LP and then MR, passing WS and then MR, and passing LP and then MR and

508 WS, which were also among the strongest connections found between seamounts in the

509 Lagrangian model (Figure 7). Besides this, the range of time spent by drifters travelling from

510 LP to MR (46-189 d) corresponded well with the PLD values for connectivity between these

511 seamounts in the model. The range of time spent by drifters between the other seamounts (29-

$51270 \mathrm{~d}$ from MR to WS, 75-143 d from WS to MR) were also consistent with the model results, 513 although slightly slower. However, we found no drifter passing MR and then LP, although 514 that is one of the strongest connections according to simulation results (Figure 7).

\subsection{Limitations of the modelling approach}

517 Numerical transport models are increasingly being used to determine patterns of larval 518 dispersal as well as connectivity between populations in the marine environment. Larval 519 dispersal simulations are relatively simple and quick to implement in any study region. 520 Indeed, data necessary for model input (coastline, release sites, etc.) are freely available 521 online at high resolutions. Nevertheless, the work accomplished during this study could be 522 improved by taking into account additional oceanographic and biological factors. 
524 We used an ocean current product (OSCAR) that relies on remote-sensing data to force the Lagrangian larval dispersal model. OSCAR currents are available globally and over long periods of time. Despite their coarse spatial resolution $\left(1 / 3^{\circ}\right)$, OSCAR and other products providing near-surface ocean current estimates have been shown to allow the simulation of surface drifter trajectories with similar accuracies as outputs from oceanographic models of similar spatial resolution (Liu et al., 2014; Amemou et al., submitted).

531 However, OSCAR does not take into account the vertical stratification of currents in the water 532 column, which may affect larval dispersal patterns. In this study, larvae were considered as 533 passive particles drifting in the surface layer, because we had no knowledge of the larval 534 biology of local species. However, the larvae of many species have good swimming ability 535 (Fisher et al., 2005) and are capable of changing their behaviour (e.g. by changing their depth) 536 in response to the environment (Leis and Carson-Ewart, 2002; Tolimieri et al., 2000). This 537 affects how larvae are carried by currents (Irisson et al., 2010; Cherubin et al., 2011), because 538 transport is usually faster close to the surface than in the deeper layers. Larvae might therefore 539 rely on vertical migration to reduce their dispersal and promote local retention (Cowen, 2002).

540 When such information is available, it is therefore important to consider larval behaviour and 541 swimming capability during larval ontogeny (Leis, 2010), and physical data such as vertical 542 stratification of currents.

544 Vianello et al. (2020, this issue) reported no clear seasonality or interannual variability in 545 currents along the Madagascar Ridge. Nevertheless, Annasawmy et al. (2019) highlighted a 546 strong seasonality in primary productivity at LP and MR, with maximum values reached in 547 July, as a result of intense mixing caused by the austral winter trade winds, and minimum 
548 values during the austral summer (December-March). Moreover, chlorophyll a (Chl-a)

549 concentrations were twice as high at MR than at LP all year round. This seasonality and the

550 differences between seamounts may have consequences on secondary productivity and thus

551 on food availability, growth and survival for larvae. Harris et al. (2020, this issue) also

552 showed that different environmental variables such as temperature, Mixed Layer Depth

553 (MLD), Depth of Chlorophyll Maximum (DCM), zooplankton settled volume and integrated

554 Chl-a, influence larval fish communities at LP, MR and WS. Therefore, environmental factors

555 and their effect on biological processes such as larval growth and mortality are important

556 factors to consider in future modelling studies.

\subsection{Perspectives}

559 From the perspective of the conservation and management of ecosystems, in particular in 560 areas beyond national jurisdiction (ABNJ) where most SWIO seamounts are located, 561 improving the understanding and knowledge of larval dispersal is crucial. A new, legally

562 binding instrument for the high seas has been discussed since 2006 under the United Nations 563 Convention on the Law of the Sea for the conservation and sustainable use of marine 564 resources beyond national jurisdiction. Larval dispersal will be a key point in designing 565 regional networks of Marine Protected Areas (Andrello et al., 2017) to conserve biodiversity 566 in the high seas efficiently. Studies using numerical models in combination with the data and 567 knowledge gathered during at-sea expeditions could make a vital contribution to these efforts. 568 Indeed, genetic data could be gathered for several species covering a range of PLD values in 569 order to corroborate the connectivity patterns simulated here between seamounts. In addition, 570 behavioural data such as larval and adult mobility, and demographic data including egg 571 production and pre- and post-settlement mortality, should also be considered, because these 
572 factors are as critical information as connectivity in determining the dynamics of populations,

573 and therefore their persistence.

574 
575 Fig. 1. Main currents of the SWIO obtained from OSCAR current data averaged over the

576

577

578

579

580

581

582

583

584 period 2010-2017, and the location of the nine studied seamounts, the eight coastal sites and surrounding countries (buffers).

Fig. 2. Trajectories of drifters passing less than $50 \mathrm{~km}$ from (a) La Pérouse, (b) MAD-Ridge and (c) Walters Shoal during their drift in the SWIO. Small white circles show the closest locations of drifters to seamounts used as the start of the represented trajectories, and small black circles are the final locations.

Fig. 3. Connectivity matrices between all seamounts and coastal sites for PLDs of (a) 15, (b) 120 and (c) $360 \mathrm{~d}$. The values represent the percentage of larvae released at each release site transported to each destination site at the given PLD. The cells in the diagonal of the matrices are values of local retention. White $=$ no connectivity $(0 \%)$. Note that the colour scale differs between panels.

Fig. 4. Connectivity matrices between seamounts and coastal ecosystems for PLDs of (a) 15, (b) 120 and (c) $360 \mathrm{~d}$. The values represent the percentage of larvae released at each release site transported to each destination site at the given PLD. The cells in the diagonal of the matrices are values of local retention. White $=$ no connectivity $(0 \%)$. Note that the colour scale differs between panels.

Fig. 5. Maps of average density for virtual larvae released at La Pérouse (a, d, g), MAD-Ridge (b, e, h) and Walters Shoal (c, f, i) for PLDs of 15, 120 and $360 \mathrm{~d}$. Pink dots are the locations 


\section{Journal Pre-proof}

598 of the drifters shown in Figure 2 at the same time (i.e. 15, 120 and $360 \mathrm{~d}$ after they passed less 599 than $50 \mathrm{~km}$ from the seamount).

600

601 Fig. 6. Local retention (\%) at La Pérouse, MAD-Ridge and Walters Shoal for PLDs of 15, 30, $60245,90,120180,270$ and $360 \mathrm{~d}$.

603

604 Fig. 7. Connectivity (\%) between La Pérouse, MAD-Ridge and Walters Shoal for PLDs of 15, $60530,45,90,120,180,270$ and $360 \mathrm{~d}$.

606

607

608

Fig. 8. Origin of the larvae reaching La Pérouse, MAD-Ridge and Walters Shoal for PLDs of

609

(a) 15 , (b) 120 and (c) $360 \mathrm{~d}$.

610 Fig. 9. Maps of average density for virtual larvae released at all seamounts and coastal sites

611 for PLDs of (a) 30, (b) 45 and (c) 90 d. These PLD correspond broadly to labrid and Apogon

612 spp., Synodus sp., and the acanthurid Naso sp., respectively.

613

614 Fig. 10. Origin of larvae reaching MAD-Ridge (imports) for PLDs of (a) 30, (b) 45 and (c) 90

$615 \mathrm{~d}$, and the destination of larvae leaving MAD-Ridge (exports) for PLDs of (d) 30, (e) 45 and

616 (f) 90 d. These PLD correspond broadly to labrid and Apogon spp., Synodus sp., and

617 acanthurid Naso sp., respectively.

618

619 Fig. 11. Age distributions of virtual larvae arriving at MAD-Ridge from (a) Fort Dauphin and

620 (b) Mamanjary, and arriving at La Pérouse from (c) La Saline and (d) Morne Brabant. 
622 Table 1. Mean distances of larval dispersal $(\mathrm{km})$ from each seamount for different Pelagic

623 Larval Durations (PLDs).

\begin{tabular}{llrrrrrrrrr}
\hline FROM \PLD & $\mathbf{1 5}$ & $\mathbf{3 0}$ & $\mathbf{4 5}$ & $\mathbf{6 0}$ & $\mathbf{9 0}$ & $\mathbf{1 2 0}$ & $\mathbf{1 8 0}$ & $\mathbf{2 7 0}$ & $\mathbf{3 6 0}$ \\
\hline La Pérouse & 167 & 283 & 355 & 423 & 540 & 628 & 793 & 1031 & 1284 \\
\hline MAD-Ridge & 337 & 460 & 575 & 665 & 804 & 901 & 1086 & 1368 & 1544 \\
\hline Walters Shoal & 109 & 217 & 296 & 348 & 439 & 517 & 678 & 869 & 1014 \\
\hline Atlantis Bank & 125 & 211 & 266 & 302 & 370 & 431 & 542 & 699 & 844 \\
\hline Sapmer Bank & 164 & 236 & 292 & 356 & 443 & 530 & 674 & 854 & 1027 \\
\hline Middle of What Seamount & 205 & 348 & 473 & 555 & 664 & 754 & 891 & 1061 & 1233 \\
\hline Coral Seamount & 342 & 605 & 847 & 1070 & 1459 & 1718 & 2086 & 2393 & 2587 \\
\hline Melville Bank & 311 & 551 & 719 & 830 & 979 & 1080 & 1256 & 1465 & 1638 \\
\hline Un-named Seamount & 195 & 279 & 394 & 452 & 523 & 622 & 782 & 974 & 1122 \\
\hline Mean & $\mathbf{2 1 7}$ & $\mathbf{3 5 4}$ & $\mathbf{4 6 9}$ & $\mathbf{5 5 6}$ & $\mathbf{6 9 1}$ & $\mathbf{7 9 8}$ & $\mathbf{9 7 6}$ & $\mathbf{1 1 9 0}$ & $\mathbf{1 3 6 6}$ \\
\hline
\end{tabular}

625 
Appendix Fig. A. Trajectories of drifters passing $<100$ km from (a) La Pérouse, (b) MAD-

627

628

629

630

631

632

633

634

635

636

637

638

639

640

641

642

643

644

645

646

647

648

649

650

Ridge and (c) Walters Shoal during their drift in the SWIO. Small white circles show the closest locations of drifters to seamounts used as the start of the represented trajectories, and small black circles are the final locations.

Appendix Fig. B. Connectivity matrices between all seamounts and coastal sites for PLDs of (a) 30, (b) 45, (c) 60, (d) 90, (e) 180 and (f) 270 d. The values represent the percentage of larvae released at each release site transported to each destination site at the given PLD. The cells in the diagonal of the matrices are values of local retention. White $=$ no connectivity $(0 \%)$. Note that the colour scale differs between panels.

Appendix Fig. C. Variability (seasonal and interannual combined) of simulated connectivity for PLDs of (a) 15, (b) 120 and (c) $360 \mathrm{~d}$. CV is the relative standard deviation (ratio of the standard deviation to the mean).

Appendix Fig. D. Connectivity matrices between seamounts and coastal ecosystems for PLDs of (a) 30, (b) 45, (c) 60, (d) 90, (e) 180 and (f) $270 \mathrm{~d}$. The values represent the percentage of larvae released at each release site and transported to each destination site at the given PLD. The cells in the diagonal of the matrices are values of local retention. White $=$ no connectivity $(0 \%)$. Note that the colour scale differs between panels.

Appendix Fig. E. Connectivity matrices between all seamounts and coastal sites for all PLDs. The buffer used around all release and destination sites was $1^{\circ}$ (instead of the $1 / 3^{\circ}$ in Fig. 3 and Appendix Fig. B). The values represent the percentage of larvae released at each release site transported to each destination site at the given PLD. The cells in the diagonal of the 
651 matrices are values of local retention. White $=$ no connectivity $(0 \%)$. Note that the colour 652 scale differs between panels.

653 


\section{References}

655 Alekseeva, E.I., 1983. Maturation of ovaries, nature of spawning and local specific character of genital cycles of alfonsino Beryx splendens Lowe from the Atlantic Ocean. In: Problems of early ontogeny of fish - theses of reports, pp. 72-73. Kaliningrad, USSR, AtlantNIRO (in Russian).

Amemou, H., Koné, V., Aman, A., Lett, C. (submitted) Assessment of a Lagrangian model using trajectories of oceanographic drifters and fishing devices in the Tropical Atlantic Ocean. Prog. Oceanogr.

Andrello, M., Guilhaumon, F., Albouy, C., Parravicini, V., Scholtens, J., Verley, P., Barange, M., Sumaila, U.R., Manel, S., Mouillot, D., 2017. Global mismatch between fishing dependency and larval supply from marine reserves. Nature Comms 8, 16039.

Andrello, M., Mouillot, D., Beuvier, J., Albouy, C., Thuiller, W., Manel, S.. 2013. Low connectivity between Mediterranean Marine Protected Areas: a biophysical modeling approach for the dusky grouper Epinephelus marginatus. PLoS ONE 8, e68564.

Annasawmy, P., Ternon, J-F., Cotel, P., Cherel, Y., Romanov, E.V., Roudaut, G., LebourgesDhaussy, A., Ménard, F., Marsac, F., 2019. Micronekton distributions and assemblages at two shallow seamounts of the south-western Indian Ocean: Insights from acoustics and mesopelagic trawl data, Prog. Oceanogr. 178, 102161. doi:10.1016/j.pocean.2019.102161

Annasawmy, P., Ternon, J-F., Lebourges-Dhaussy, A., Roudaut, G., Herbette, S., Ménard, F., Cotel, P., Marsac, F., 2020. Micronekton distribution as influenced by mesoscale eddies, Madagascar shelf and shallow seamounts in the south-western Indian Ocean: an acoustic approach. Deep-Sea Res. II. (this issue).

Armsworth, P.R. 2002. Recruitment limitation, population regulation, and larval connectivity in reef fish metapopulations. Ecology 83, 1092-1104.

Boehlert, G.W., Watson, W., Sun, L.C., 1992. Horizontal and vertical distributions of larval fishes around an isolated oceanic island in the tropical Pacific. Deep Sea Res. A.

Oceanographic Research Papers, 39(3-4), 439-466.

Bonjean, F., Lagerloef, G.S.E., 2002. Diagnostic model and analysis of the surface currents in the tropical Pacific Ocean. J. Phys. Oceanogr. 32(10), 2938-2954.

Booth, J.D., 2006. Jasus species. In: Phillips B.F. (ed.) Lobsters: Biology, Management, Aquaculture and Fisheries. Blackwell Scientific, Oxford, pp 340-358.

Bryan-Brown, D.N., Brown, C.J., Hughes, J.M., Connolly, R.M., 2018. Patterns and trends in marine population connectivity research. Mar. Ecol. Prog. Ser. 585, 243-256. https://doi.org/10.3354/meps 12418

Burgess, S.C., Nickols, K.J., Griesemer, C.D., Barnett, L.A., Dedrick, A.G., Satterthwaite, E.V., et al., 2014. Beyond connectivity: how empirical methods can quantify population persistence to improve marine protected-area design. Ecol. Appl. 24, 257-270. doi: 10.1890/13-0710.1. 
703

704

705

706

707

708

709

710

711

712

713

714

715

716

717

718

719

720

721

722

723

724

725

726

727

728

729

730

731

732

733

734

735

736

737

738

739

740

741

742

743

744

745

746

747

748

749

750

Chapman, P., Marco, S.F.D., Davis, R., Coward, A., 2003. Flow at intermediate depths around Madagascar based on ALACE float trajectories. Deep Sea Res. II: Topical Studies in Oceanography 50, 1957-1986. doi:10.1016/S0967-0645(03)00040-7

Cherel, Y., Romanov, E.V., Annasawmy, P., Thibault, D., Ménard, F., 2020. Micronektonic fish species over three seamounts in the southwestern Indian Ocean. Deep-Sea Res. II. (this issue).

Cherubin, L.M., Nemeth, R.S., Idrisi, N., 2011. Flow and transport characteristics at an Epinephelus guttatus (red hind grouper) spawning aggregation site in St Thomas (US Virgin Islands). Ecol. Model. 222, 3132-3148. doi:10.1016/j.ecolmodel.2011.05.031

Cinner, J.E., Huchery, C., MacNeil, M.A., Graham, N.A.J., McClanahan, T.R., Maina, J., et al., 2016. Bright spots among the world's coral reefs. Nature 535, 416-419.

Clark, M.R., Schlacher, T.., Rowden, A.A., Stocks, K.I., Consalvey, M., 2012. Science priorities for seamounts: research links to conservation and management. PLoS ONE 7, e29232, doi:10.1371.

Cowen, R.K., 2002. Larval dispersal and retention and consequences for population connectivity. In: Sale, P.F. (ed.), Coral Reef Fishes: Dynamics and Diversity in a Complex Ecosystem. Academic Press, London. pp. 149-170.

Cowen, R.K., Gawarkiewicz, G., Pineda, J., Thorrold, S., Werner, F., 2007. Population connectivity in marine systems: an overview. Oceanography 20, 14-21. https://doi.org/10.5670/oceanog.2007.26.

Cowen, R.K., Lwiza, K.M.M., Sponaugle, S., Paris, C.B., Olson, D.B., 2000. Connectivity of marine populations: open or closed? Science 287, 857.

Crochelet, E., Chabanet, P., Pothin, K., Lagabrielle, E., Roberts, J., Pennober, G., LecomteFiniger, R. and Petit, M., 2013. Validation of a fish larvae dispersal model with otolith data in the western Indian Ocean and implications for marine spatial planning in data-poor regions. Ocean Coast. Mgmt 86, pp.13-21.

Crochelet, E., Roberts, J., Lagabrielle, E., Obura, D., Petit, M., Chabanet, P., 2016. A modelbased assessment of reef larvae dispersal in the Western Indian Ocean reveals regional connectivity patterns_-potential implications for conservation policies. Reg Stud. Mar. Sci. 7, pp.159-167.

de Ruijter, W.P.M., van Aken, H.M., Beier, E.J., Lutjeharms, J.R.E., Matano, R.P., Schouten, M.W., Schlitzer, R., 2004. Eddies and dipoles around South Madagascar: formation, pathways and large-scale impact. Deep Sea Res. 51, 383-400.

Doherty, P. J., Planes, S., Mather, P., 1995. Gene flow and larval duration in seven species of fish from the Great Barrier Reef. Ecology, 76(8), 2373-2391. 
Edgar, G.J., Stuart-Smith, R.D., Willis, T.J., Kininmonth, S., Baker, S.C., Banks, S., et al., 2014. Global conservation outcomes depend on marine protected areas with five key features.

753

754

755

756

757

758

759

760

761

762

763

764

765

766

767

768

769

770

771

772

773

774

775

776

777

778

779

780

781

782

783

784

785

786

787

788

789

790

791

792

793

794

795

796

797

798

Nature 506, 216-220.

Faillettaz, R., Paris, C.B., Irisson, J-O., 2018. Larval fish swimming behavior alters dispersal patterns from Marine Protected Areas in the North-Western Mediterranean Sea. Front. Mar. Sci. 5, 97. doi: 10.3389/fmars.2018.00097

FAO, 2018. The State of World Fisheries and Aquaculture 2018 - Meeting the sustainable development goals. Rome, FAO.

FFEM, 2013. Note d'Engagement de Projet (NEP). Conservation et exploitation durable des écosystèmes de monts sous-marins et sources hydrothermales du Sud-Ouest de l'Océan Indien au-delà des zones de juridiction nationale. 67 pp.

Fisher, R., Leis, J.M., Clark, D.L., Wilson, S.K., 2005. Critical swimming speeds of late-stage coral reef fish larvae: variation within species, among species and between locations. Mar. Biol. 147, 1201-1212.

Gamoyo, M., Obura, D., Reason, C.J.C., 2019. Estimating connectivity through larval dispersal in the Western Indian Ocean. J. Geophys. Res. Biogeosci. 124, 2446-2459. https://doi.org/10.1029/2019JG005128

Groeneveld, J.C., Griffiths, C.L., van Dalsen, A.P., 2006. A new species of spiny lobster, Palinurus barbarae (Decapoda, Palinuridae) from Walters Shoals on the Madagascar Ridge. Crustaceana 79(7), 821-823.

Guinot, D., Richer de Forges, B., 1981. Crabes de profondeur, nouveaux ou rares, de l'IndoPacifique (Crustacea, Decapoda, Brachyura). Bulletin du Muséum national d'Histoire naturelle, 1ère partie 4(2), 1113-1153. 2ème partie 4(3), 227-260.

Guinotte, J., 2011. Seamount map of the Indian Ocean. Marine Conservation Biology Institute; 3 pp. http://www.savethehighseas.org/publicdocs/Indian-Ocean-map.pdf

Harris, S., Noyon, M., Roberts, M.J., Marsac, F., 2020. Ichthyoplankton assemblages at three shallow seamounts in the South West Indian Ocean: La Pérouse, MAD-Ridge and Walters Shoal. Deep-Sea Res. II. (this issue).

Hastings, A., Botsford, L.W., 2006. Persistence of spatial populations depends on returning home. Proc. Natl Acad. Sci. 103, 6067-6072. doi: 10.1073/pnas.0506651103 PMID: 16608913

Hellberg, M.E., 2007. Footprints on water: the genetic wake of dispersal among reefs. Coral Reefs 26, 463-473.

Irisson, J.O., Paris, C.B., Guigand, C.M., Planes, S., 2010. Vertical distribution and ontogenetic 'migration' in coral reef fish larvae. Limnol. Oceanogr. 55, 909-919. 
Jones, G.P., Almany, G.R., Russ, G.R., Sale, P.F., Steneck, R.S., van Oppen, M.J.H., et al., 2009. Larval retention and connectivity among populations of corals and reef fishes: history, advances and challenges. Coral Reefs 28, 307-325.

802

803

804

805

806

807

808

809

810

811

812

813

814

815

816

817

818

819

820

821

822

823

824

825

826

827

828

829

830

831

832

833

834

835

836

837

838

839

840

841

842

843

844

845

846

847

Kingsford, M.J., Leis, J.M., Shanks, A., Lindeman, K.C., Morgan, S.G., Pineda, J., 2002. Sensory environments, larval abilities and local self-recruitment. Bull. Mar. Sci. 70, 309-340.

Koslow, J.A., Boehlert, G.W., Gordon, J.D.M., Haedrich, R.L., Lorance, P., Parin, N., 2000. Continental slope and deep-sea fisheries: implications for a fragile ecosystem. ICES J. Mar. Sci. 57, 548-557.

Leis, J.M., 1984. Larval fish dispersal and the east Pacific Barrier. Océanogr. Trop. 19, 181192.

Leis, J.M., 1991. The pelagic phase of coral reef fishes: larval biology of coral reef fishes. pp. 183-230. In: Sale, P.F. (ed.). The Ecology of Fishes on Coral Reefs, Academic Press, San Diego. 754 pp.

Leis, J., 2002. Pacific coral-reef fishes: the implications of behaviour and ecology of larvae for biodiversity and conservation, and a reassessment of the open population paradigm. Env. Biol. Fish. 65, 199-208.

Leis, J., 2010. Ontogeny of behaviour in larvae of marine demersal fishes. Ichthyol. Res 57, 325-342. doi:10.1007/s10228-010-0177-z

Leis, J.M., Carson-Ewart, B.M., 2002. In situ settlement behaviour of damselfish (Pomacentridae) larvae. J. Fish Biol. 61, 325-346.

Lett, C., Verley, P., Mullon, C., Parada, C., Brochier, T., Penven, P., Blanke, B., 2008. A Lagrangian tool for modelling ichthyoplankton dynamics. Env. Model. Softw. 23, 1210-1214. doi:10.1016/j.envsoft.2008.02.005

Liu, Y., Weisberg, R.H., Vignudelli, S., Mitchum, G.T., 2014. Evaluation of altimetry-derived surface current products using Lagrangian drifter trajectories in the eastern Gulf of Mexico. J. Geophys. Res.: Oceans 119, 2827-2842. https://doi.org/10.1002/2013JC009710.

Luiz, O.J., Allen, A.P., Robertson, D.R., Floeter, S.R., Kulbicki, M., Vigliola, L., Becheler, R., Madin, J.S., 2013. Adult and larval traits as determinants of geographic range size among tropical reef fishes. Proc. Nat. Acad. Sci., 110(41), 16498-16502. https://doi.org/10.1073/pnas.1304074110

Lumpkin, R., Centurioni, L., 2019. Global Drifter Program quality-controlled 6-hour interpolated data from ocean surface drifting buoys. NOAA National Centers for Environmental Information. Dataset. https://doi.org/10.25921/7ntx-z961.

Maina, J.M., Gamoyo, M., Adams, V.M., D’agata, S., Bosire, J., Francis, J., Waruinge, D., 2020. Aligning marine spatial conservation priorities with functional connectivity across maritime jurisdictions. Conserv. Sci. Practice. https://doi.org/10.1111/csp2.156 
Manel, S., Loiseau, N., Andrello, M., Fietz, K., Goñi, R., Forcada, A., Lenfant, P., Kininmonth, S., Marcos, C., Marques, V., Mallol, S., Pérez-Ruzafa, A., Breusing, C., Puebla, O., Mouillot, D., 2019. Long-distance benefits of marine reserves: myth or reality? Trends Ecol. Evol. 34, 342-354. https://doi.org/10.1016/j.tree.2019.01.002

Marsac, F., Annasawmy, P., Noyon, M., Demarcq, H., Soria, M., Rabearisoa, N., Bach, P., Cherel, Y., Grelet, J., Romanov, E.V. Physical environment and ecological interactions at and near La Pérouse seamount, northwest of Réunion Island, Indian Ocean. Deep Sea Res. II (this issue).

Mattio, L., Zubia, M., Loveday, B., Crochelet, E., Duong, N., Payri, C.E., Bhagooli, R., Bolton, J.J., 2013. Sargassum (Fucales, Phaeophyceae) in Mauritius and Réunion, western Indian Ocean: taxonomic revision and biogeography using hydrodynamic dispersal models. Phycologia 52, 578-594. https://doi.org/10.2216/13-150.1

Moberg, F., Folke, C., 1999. Ecological goods and services of coral reef ecosystems. Ecol. Econ. 29, 215-233.

Mora, C., Treml, E.A., Roberts, J., Crosby, K., Roy, D., Tittensor, D.P., 2012. High connectivity among habitats precludes the relationship between dispersal and range size in tropical reef fishes. Ecography 35, 89-96. doi:10.1111/j.1600-0587.2011.06874.x

Morato, T., Cheung, W.W.L., Pitcher T.J., 2004. Addition to Froese and Sampang's checklist of seamount fishes. In: Morato, T., Pauly, D. (eds). Seamounts: Biodiversity and Fisheries. Fisheries Centre Research Reports, 12 (5), Appendix 1: 1-6. Fisheries Centre, University of British Columbia, Canada.

Obura, D., 2012. The diversity and biogeography of Western Indian Ocean reef-building corals. PLoS ONE 7(9), e45013. https://doi.org/10.1371/journal.pone.0045013

Peliz, A., Marchesiello, P., Dubert, J., Marta-Almeida, M., Roy, C., Queiroga, H., 2007. A study of crab larvae dispersal on the western Iberian Shelf: physical processes. J. Mar. Syst. $68,215-236$.

Pineda, J., Reyns, N.B., Starczak, V.R., 2009. Complexity and simplification in understanding recruitment in benthic populations. Pop. Ecol. 51, 17-32. DOI: 10.1007/s10144-008-0118-0

Planes, S., Doherty, P.J., Bernardi, G., 2001. Strong genetic divergence among populations of a marine fish with limited dispersal, Acanthochromis polyacanthus, within the Great Barrier Reef and the Coral Sea. Evolution 55, 2263-2273.

Pollard, R., Read, J., 2017. Circulation, stratification and seamounts in the Southwest Indian Ocean. Deep Sea Res. Part II. Top. Stud. Oceanogr. 136, 36-43. https://doi.org/10.1016/j.dsr2.2015.02.018.

Popova, E., Vousden, D., Sauer, W.H., Mohammed, E.Y., Allain, V., Downey-Breedt, N., Fletcher, R., Gjerde, K.M., Halpin, P.N., Kelly, S., Obura, D., 2019. Ecological connectivity between the areas beyond national jurisdiction and coastal waters: safeguarding interests of coastal communities in developing countries. Mar. Pol. 104, 90-102. 
Pous, S., Feunteun, E., Ellien, C., 2010. Investigation of tropical eel spawning area in the

899

900

901

902

903

904

905

906

907

908

909

910

911

912

913

914

915

916

917

918

919

920

921

922

923

924

925

926

927

928

929

930

931

932

933

934

935

936

937

938

939

940

941

942

943

944

945

946

South-Western Indian Ocean: influence of the oceanic circulation. Prog. Oceanogr. 86, 396413. https://doi.org/10.1016/j.pocean.2010.06.002.

Read, J., Pollard, R., 2017. An introduction to the physical oceanography of six seamounts in the southwest Indian Ocean. Deep Sea Res. II: Topical Studies in Oceanography 136, 44-58. https://doi.org/10.1016/j.dsr2.2015.06.022.

Reid, K., Crochelet, E., Bloomer, P., Hoareau, T.B., 2016. Investigating the origin of vagrant dusky groupers, Epinephelus marginatus (Lowe, 1834), in coastal waters of Réunion Island. Mol. Phylogen. Evol. 103, 98-103.

Riginos, C., Victor, B.C., 2001. Larval spatial distributions and other early life-history characteristics predict genetic differentiation in eastern Pacific blennioid fishes. Proc. R. Soc. Lond.. Series B: Biological Sciences, 268(1479), 1931-1936.

Roberts, C.M., 1997. Connectivity and management of Caribbean coral reefs. Science 278, 1454-1457. doi:10.1126/science.278.5342.1454

Roberts, M.J., Ternon, J-F., Marsac, F., Noyon, M., 2020. The MAD-Ridge Project: biophysical coupling around a shallow seamount on the northern Madagascar Ridge, Southwest Indian Ocean. Deep-Sea Res. II. (this issue).

Rogers, A.D., 2012. An Ecosystem Approach to Management of Seamounts in the Southern Indian Ocean. 1. Overview of Seamount Ecosystems and Biodiversity. IUCN, Gland, Switzerland. $60 \mathrm{pp}$.

Rogers, A.D., Alvheim, O., Bemanaja, E., Benivary, D., Boersch-Supan, P., Bornman, T.G., Cedras, R., Du Plessis, N., Gotheil, S., Høines, A., Kemp, K., Kristiansen, J., Letessier, T., Mangar, V., Mazungula, N., Mørk, T., Pinet, P., Pollard, R., Read, J., Sonnekus, T., 2017. Pelagic communities of the South West Indian Ocean seamounts: R/V Dr Fridtjof Nansen Cruise 2009-410. Deep-Sea Res. II: Topical Studies in Oceanography 136, 5-35. doi:10.1016/j.dsr2.2016.12.010

Romanov, E.V., 2003. Summary and review of Soviet and Ukrainian scientific and commercial fishing operations on the deepwater ridges of the Southern Indian Ocean. In: Romanov, E.V. (ed.). FAO Fish. Circ. 991, 84 pp.

Rowden, A.A., Dower, J.F., Schlacher, T.A., Consalvey, M., Clark, M.R., 2010. Paradigms in seamount ecology: fact, fiction, and future. Mar. Ecol. 31(Suppl. 1), 226-239.

Schleyer, M.H., Downey-Breedt, N.J., Benayahu, Y., 2019. Species composition of Alcyonacea (Octocorallia) on coral reefs at Europa Island and associated connectivity across the Mozambique Channel. Mar. Biodiv. 49, 2485-2491. https://doi.org/10.1007/s12526-01900975-7.

Schultz, E.T., Cowen, R.K., 1994. Recruitment of coral reef fishes to Bermuda: 1Lcal retention or long-distance transport? Mar. Ecol. Prog. Ser. 109, 15-28. 
957

958

959

960

961

962

963

964

965

966

967

968

969

970

971

972

973

974

975

976

977

978

979

980

981

982

983

984

985

986

987

988

989

990

991

992

993

994

995

Selkoe, K.A., Toonen, R.J., 2011. Marine connectivity: a new look at pelagic larval duration and genetic metrics of dispersal. Mar. Ecol. Prog. Ser. 436, 291-305.

SIOFA, 2019. Report of the Fourth Session of the Scientific Committee (SC4), p. 195, 25- 29 March 2019, Yokohama.

Shotton, R., 2006. Management of demersal fisheries resources of the southern Indian Ocean. FAO Fish. Circ. 1020, 90 pp.

Shotton, R., 2016. Global review of alfonsino (Beryx spp.), their fisheries, biology and management. FAO Fish. Aquacult. Circ. C1084, 154 pp.

Sikhakolli, R., Sharma, R., Basu, S., Gohil, B.S., Sarkar, A., Prasad, K.V.S.R., 2013. Evaluation of OSCAR ocean surface current product in the tropical Indian Ocean using in situ data. J. Earth Syst. Sci. 122, 187-199. doi:10.1007/s12040-012-0258-7

Stier, A.C., Hein, A.N., Parravicini, V., Kulbicki, M., 2014. Larval dispersal drives trophic structure across Pacific coral reefs. Nat. Comms, doi: 10.1038/ncomms6575

Tolimieri, N., Jeffs, A., Montgomery, J., 2000. Ambient sound as a cue for navigation by the pelagic larvae of reef fishes. Mar. Ecol. Prog. Ser. 207, 219-224. doi:10.3354/meps207219

Tomczak, M., Godfrey, J.S., 2003. Regional Oceanography: an Introduction, 2nd edn. Daya Publishing House, Delhi. 390 pp.

Treml, E.A., Halpin, P.N., Urban, D.L., Pratson, L.F., 2008. Modeling population connectivity by ocean currents, a graph-theoretic approach for marine conservation. Landscape Ecol. 23, 19-36.

UNEP-Nairobi Convention and WIOMSA (2015). The Regional State of the Coast Report: Western Indian Ocean. UNEP and WIOMSA, Nairobi, Kenya, 546 pp.

Van der Stocken, T., Menemenlis, D., 2017. Modelling mangrove propagule dispersal trajectories using high-resolution estimates of ocean surface winds and currents, Biotropica 49, 472-481. https://doi.org/10.1111/btp.12440.

Vianello, P., Herbette, S., Ternon, J-F., Demarcq, H., Roberts, M.J., 2020. Circulation and hydrography in the vicinity of a shallow seamount on the northern Madagascar Ridge. DeepSea Res. II. (this issue).

Victor, B.C., 1987. Growth, dispersal, and identification of planktonic labrid and pomacentrid reef-fish larvae in the eastern Pacific Ocean. Mar. Biol. 95, 145-152. doi:10.1007/BF00447496

Warner, R.R., Cowen, R.K., 2002. Local retention of production in marine populations: evidence, mechanisms, and consequences. Bull. Mar. Sci. 70, 245-249.

Zucchi, S., Ternon, J-F., Demarcq, H., Ménard, F., Guduff, S., Spadone, A., 2018. Oasis for marine life. State of knowledge on seamounts and hydrothermal vents. IUCN, Gland, 
996 Switzerland, vi +50 pp. ISBN: $978-2-8317-1934-4 \quad$ (PDF). $\quad$ DOI: 997 10.2305/IUCN.CH.2018.14.en-fr 998 
999 Formatting of funding sources

1000 This work was partly carried out in the framework of the project P00917 entitled 1001 "Conservation and sustainable exploitation of seamount and hydrothermal wind ecosystems of 1002 the South West Indian Ocean in areas beyond national jurisdiction", funded by the French 1003 Global Environment Facility (FFEM), and conducted from 2014 to 2018.

1004 
Table 1. Mean distances of larval dispersal $(\mathrm{km})$ from each seamount for different Pelagic Larval Durations (PLDs).

\begin{tabular}{|l|r|r|r|r|r|r|r|r|r|}
\hline FROM \PLD & $\mathbf{1 5}$ & $\mathbf{3 0}$ & $\mathbf{4 5}$ & $\mathbf{6 0}$ & $\mathbf{9 0}$ & $\mathbf{1 2 0}$ & $\mathbf{1 8 0}$ & $\mathbf{2 7 0}$ & $\mathbf{3 6 0}$ \\
\hline La Perouse & 167 & 283 & 355 & 423 & 540 & 628 & 793 & 1031 & 1284 \\
\hline MAD-Ridge & 337 & 460 & 575 & 665 & 804 & 901 & 1086 & 1368 & 1544 \\
\hline Walters Shoal & 109 & 217 & 296 & 348 & 439 & 517 & 678 & 869 & 1014 \\
\hline Atlantis Bank & 125 & 211 & 266 & 302 & 370 & 431 & 542 & 699 & 844 \\
\hline Sapmer Bank & 164 & 236 & 292 & 356 & 443 & 530 & 674 & 854 & 1027 \\
\hline Middle of What Seamount & 205 & 348 & 473 & 555 & 664 & 754 & 891 & 1061 & 1233 \\
\hline Coral Seamount & 342 & 605 & 847 & 1070 & 1459 & 1718 & 2086 & 2393 & 2587 \\
\hline Melville Bank & 311 & 551 & 719 & 830 & 979 & 1080 & 1256 & 1465 & 1638 \\
\hline Un-named Seamount & 195 & 279 & 394 & 452 & 523 & 622 & 782 & 974 & 1122 \\
\hline Mean & $\mathbf{2 1 7}$ & $\mathbf{3 5 4}$ & $\mathbf{4 6 9}$ & $\mathbf{5 5 6}$ & $\mathbf{6 9 1}$ & $\mathbf{7 9 8}$ & $\mathbf{9 7 6}$ & $\mathbf{1 1 9 0}$ & $\mathbf{1 3 6 6}$ \\
\hline
\end{tabular}




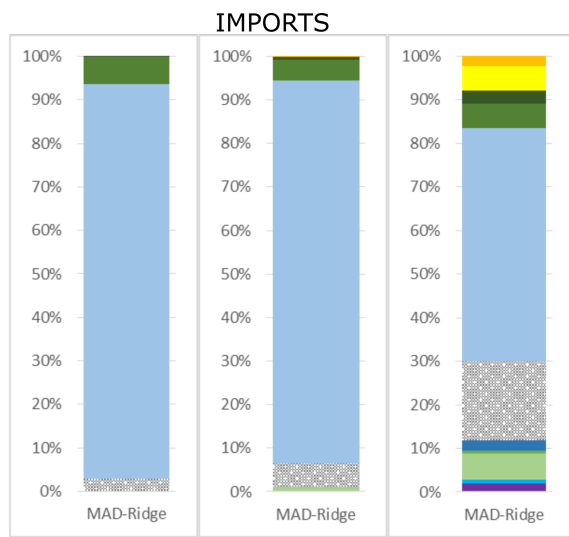

Day 030 a) Day 045 b) Day 090 c)

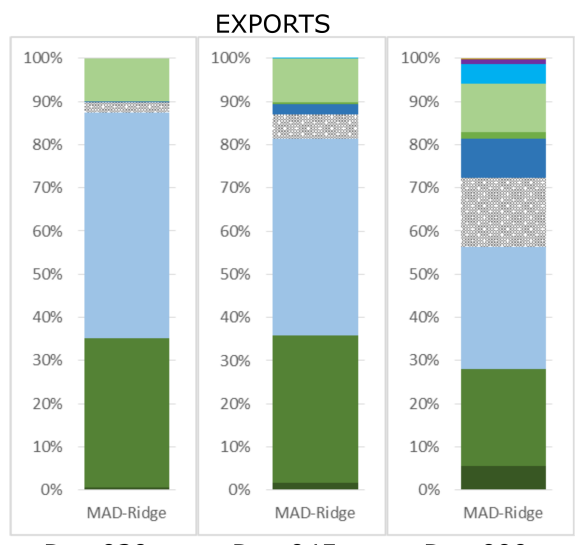

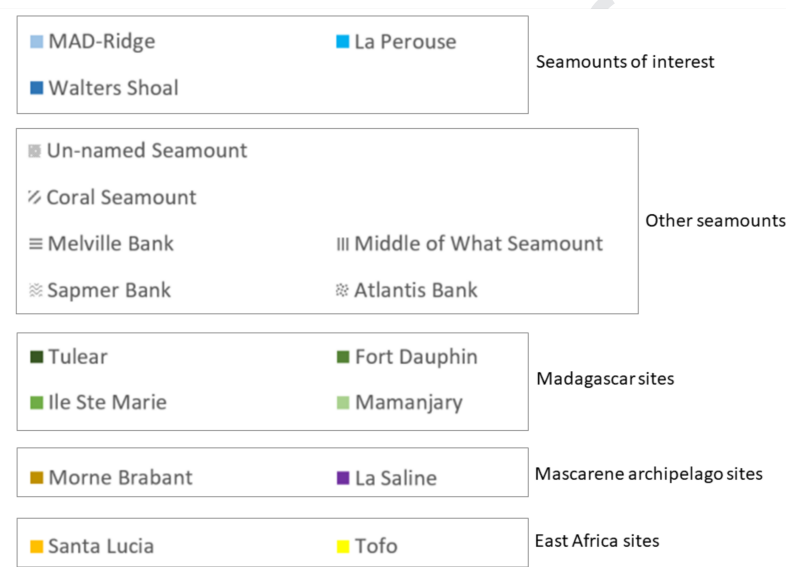

Day 030

d)

Day 045

Day 090 

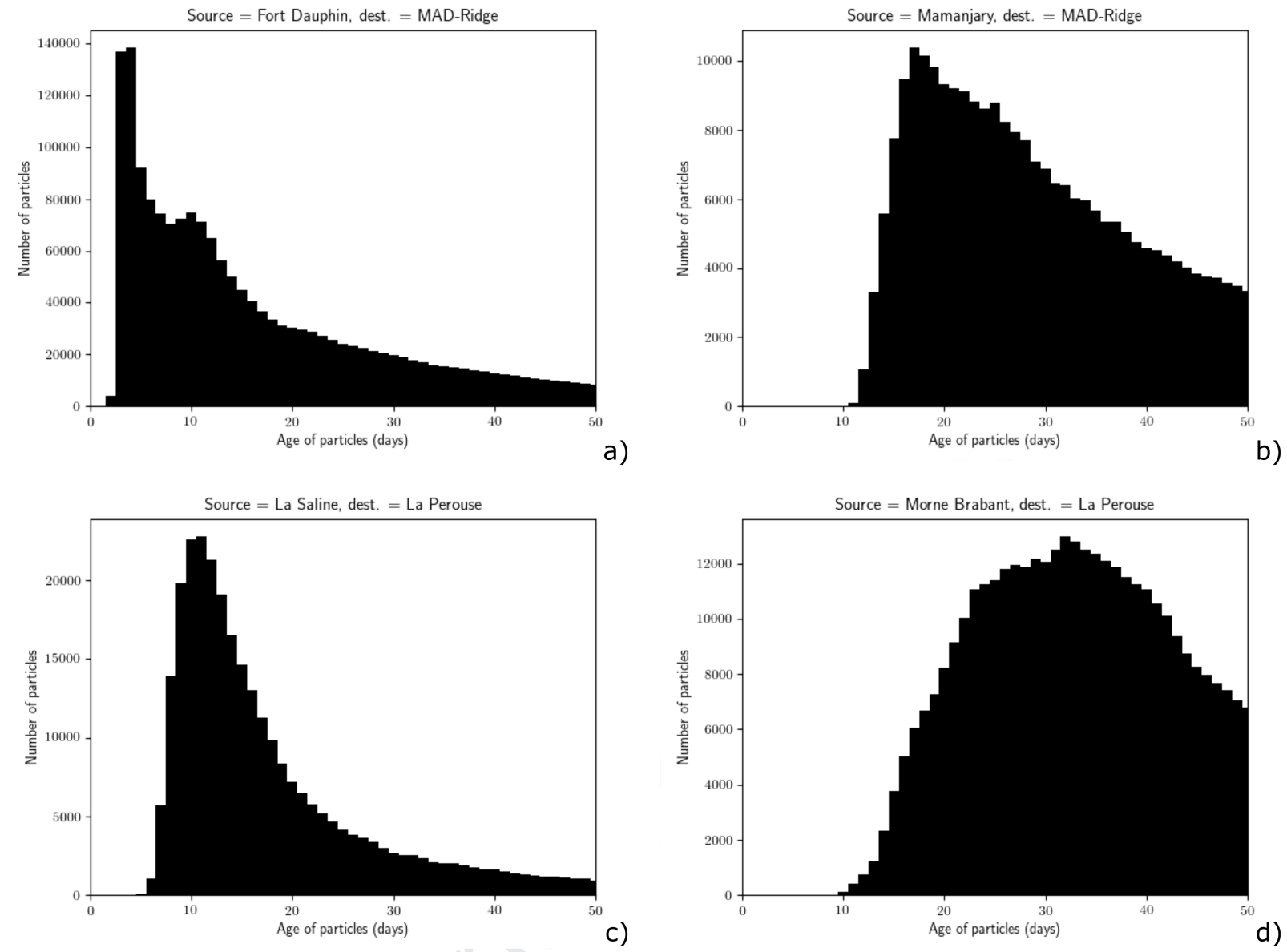


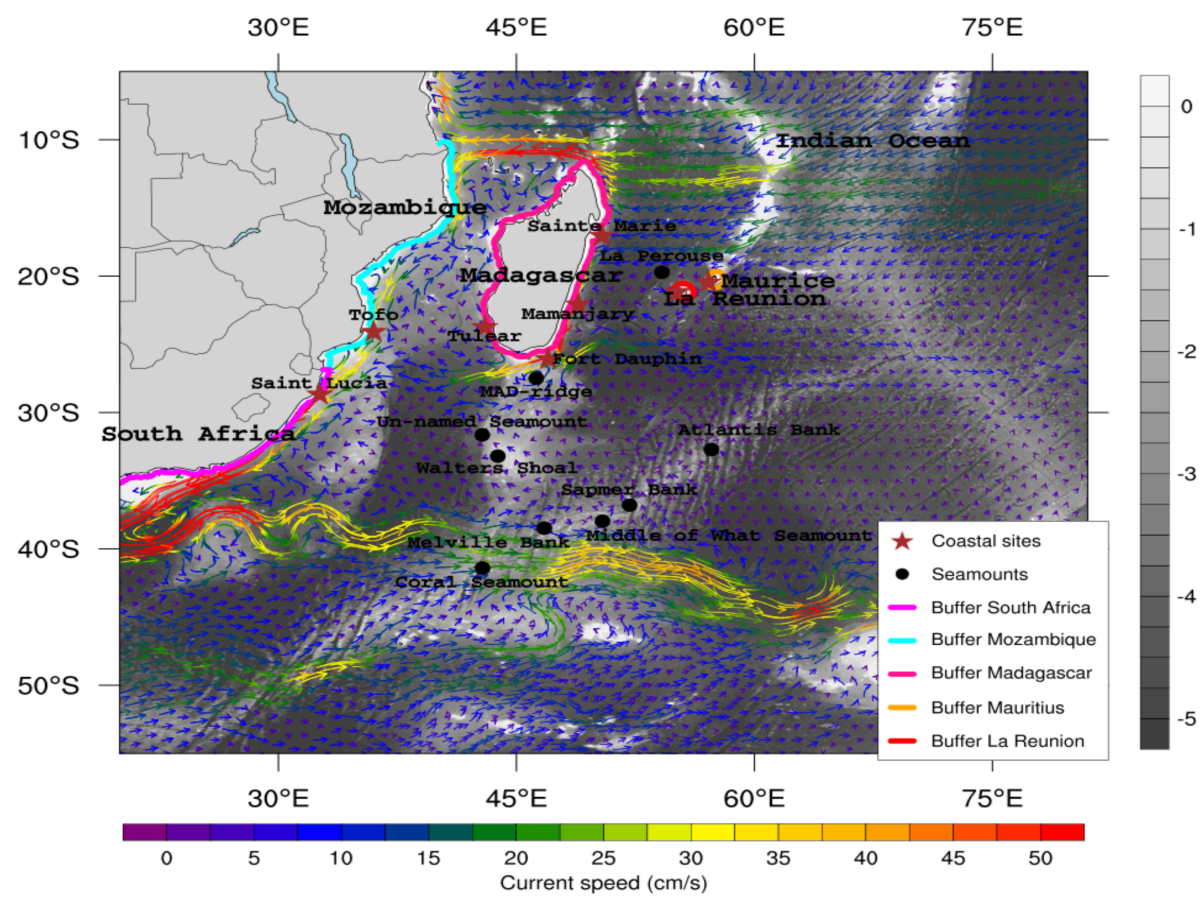

\begin{tabular}{|c|c|}
\hline Name & $\begin{array}{c}\text { Summit } \\
\text { depth } \\
\text { (meters) }\end{array}$ \\
\hline Atlantis Bank & 690 \\
\hline Sapmer Bank & 261 \\
\hline $\begin{array}{l}\text { Middle of What } \\
\text { Seamount }\end{array}$ & 876 \\
\hline Coral Seamount & 175 \\
\hline Melville Bank & 91 \\
\hline $\begin{array}{l}\text { Un-named } \\
\text { Seamount }\end{array}$ & 1249 \\
\hline Walter's Shoal & 18 \\
\hline La Pérouse & 55 \\
\hline MAD-Ridge & 240 \\
\hline
\end{tabular}



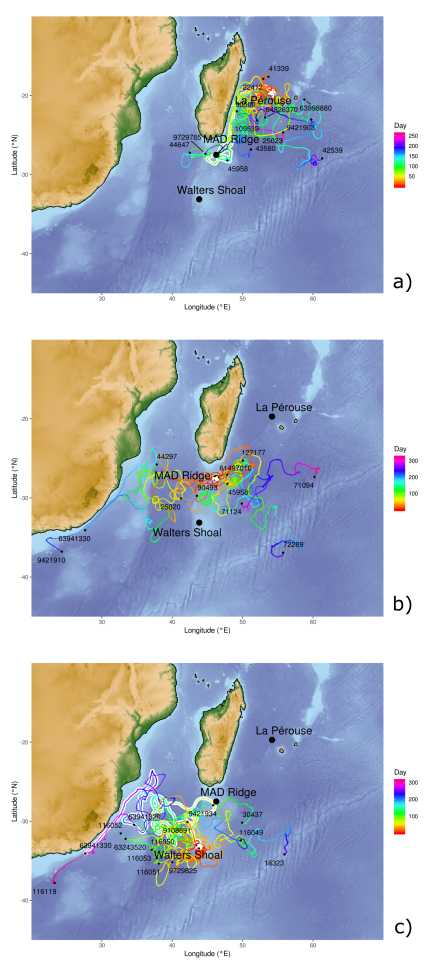

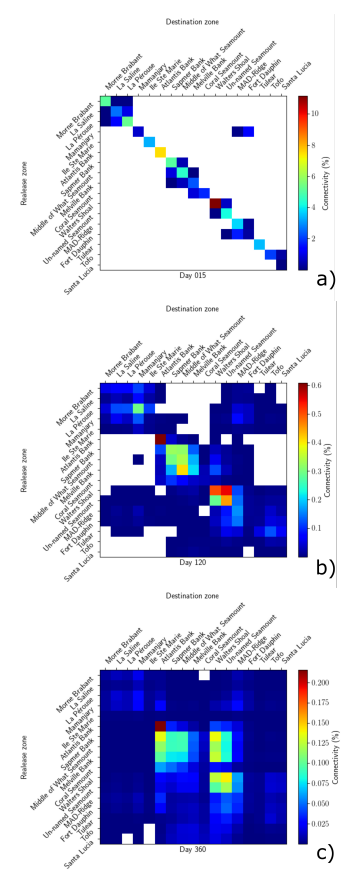

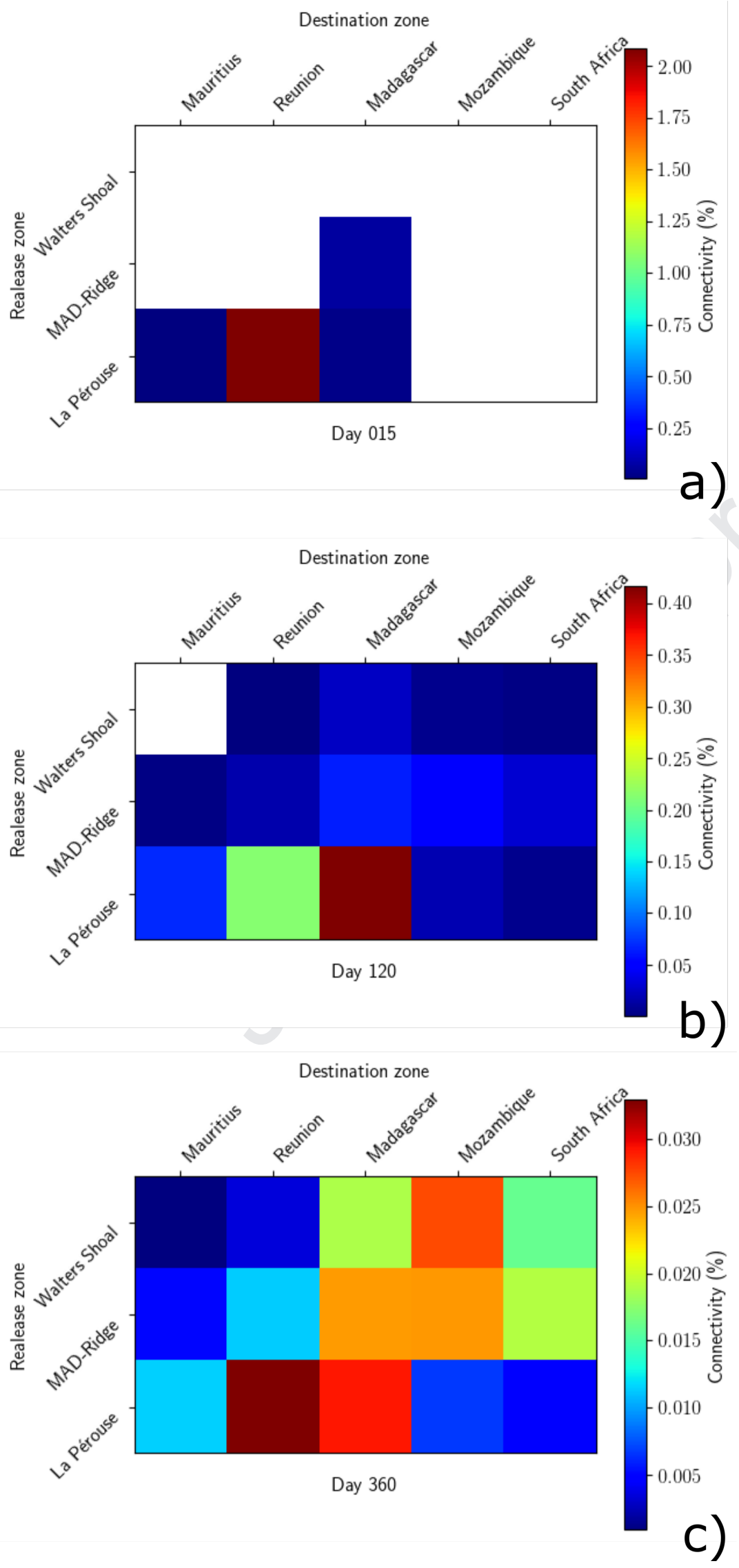
La Pérouse

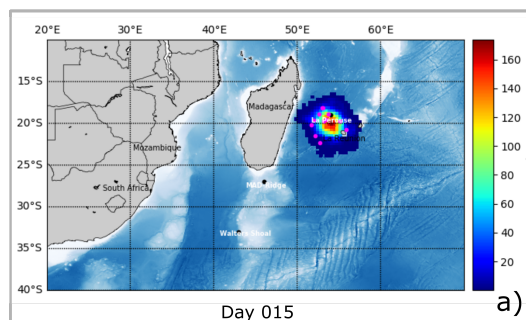

Day 015

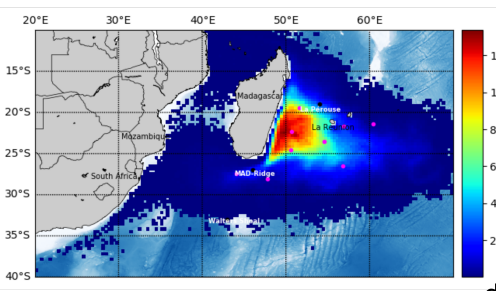

Day 120

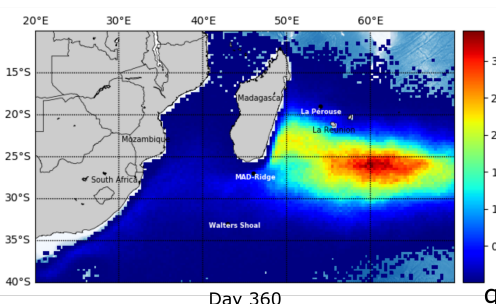

MAD-Ridge

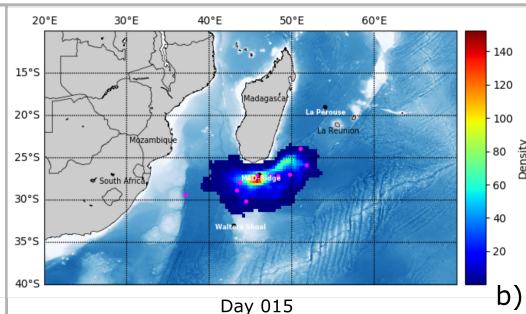

Day 015

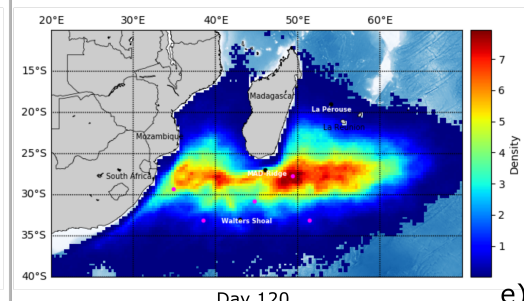

Day 120

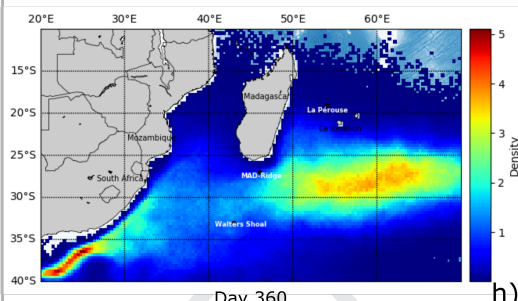

e)
Walters Shoal
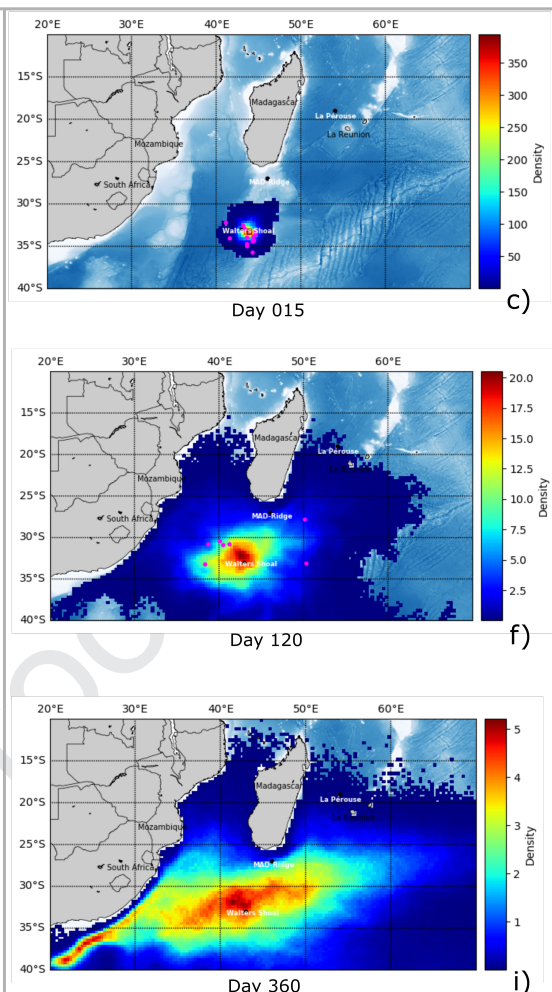


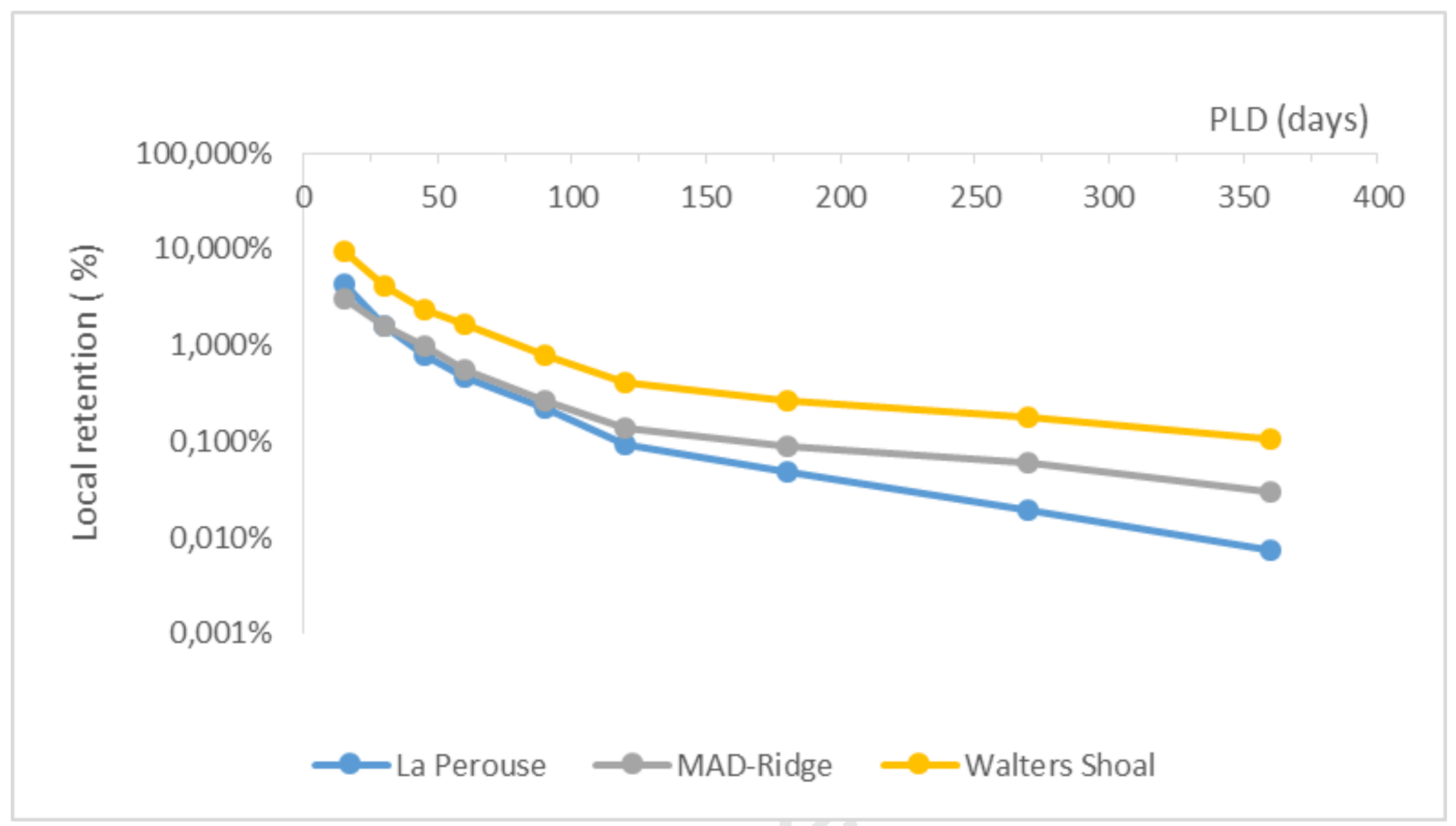




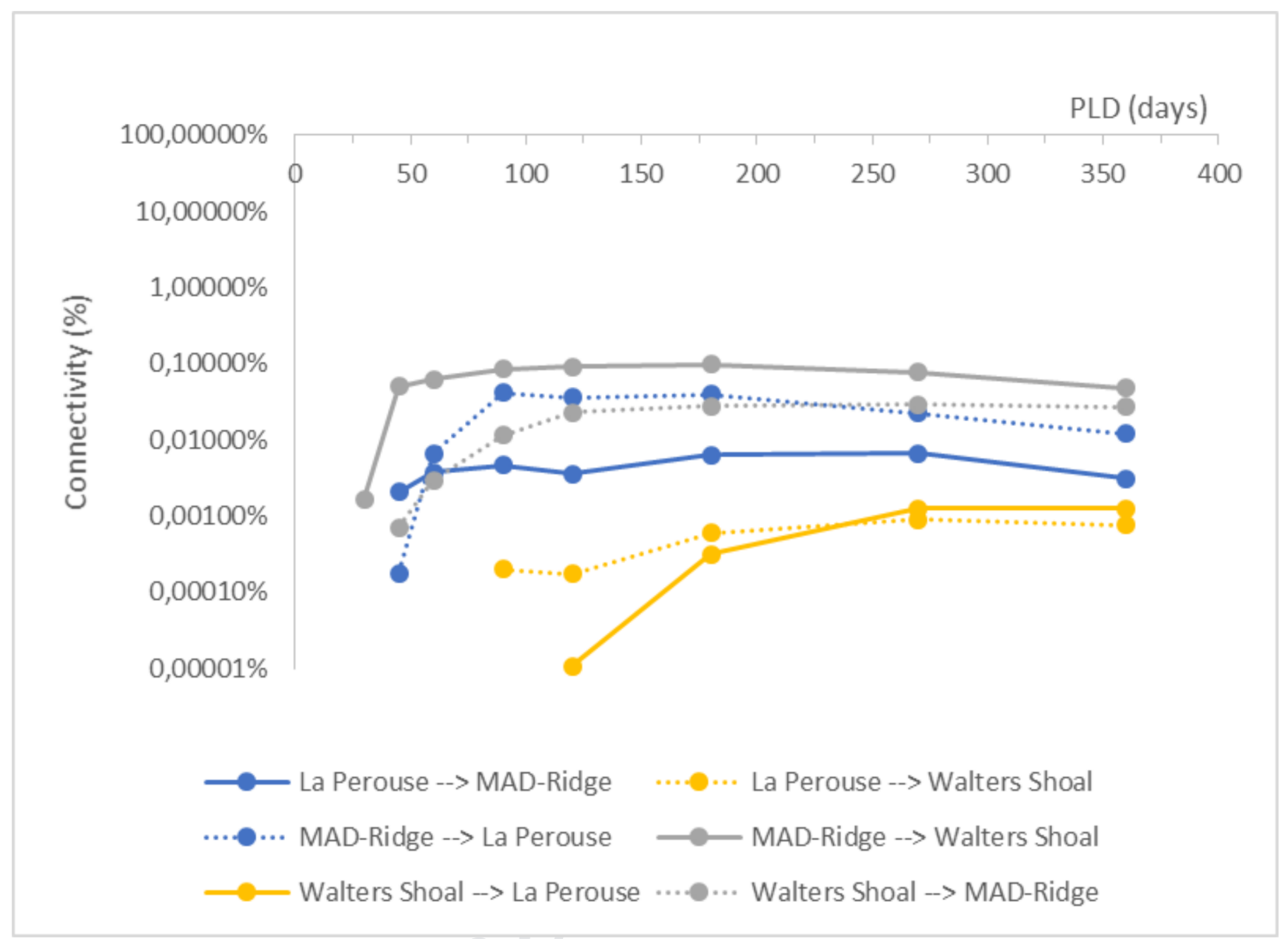



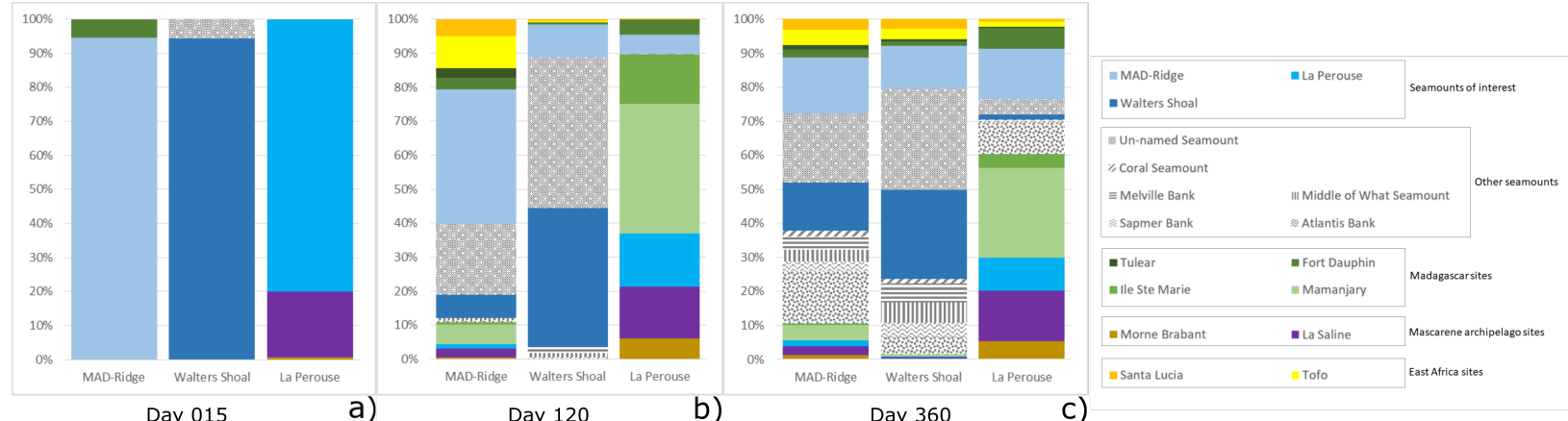

Day 015

a)

Day 120

b)

C) 

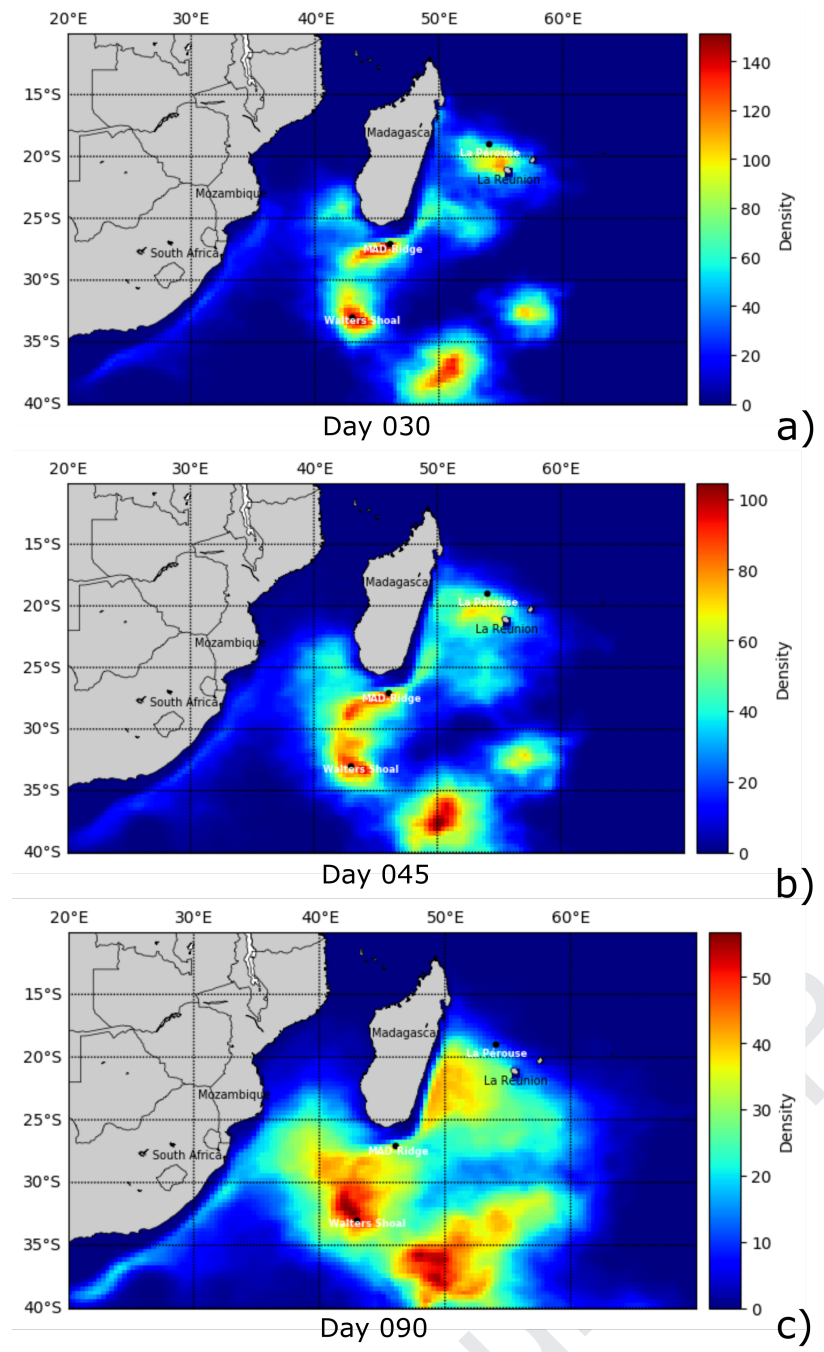

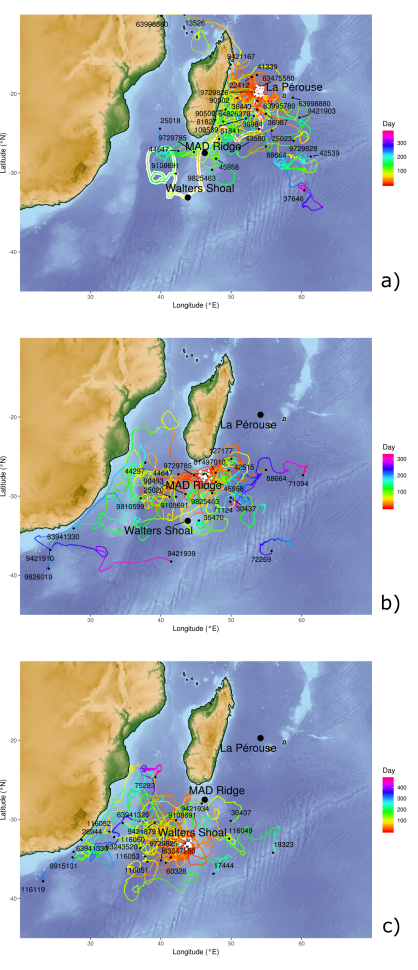

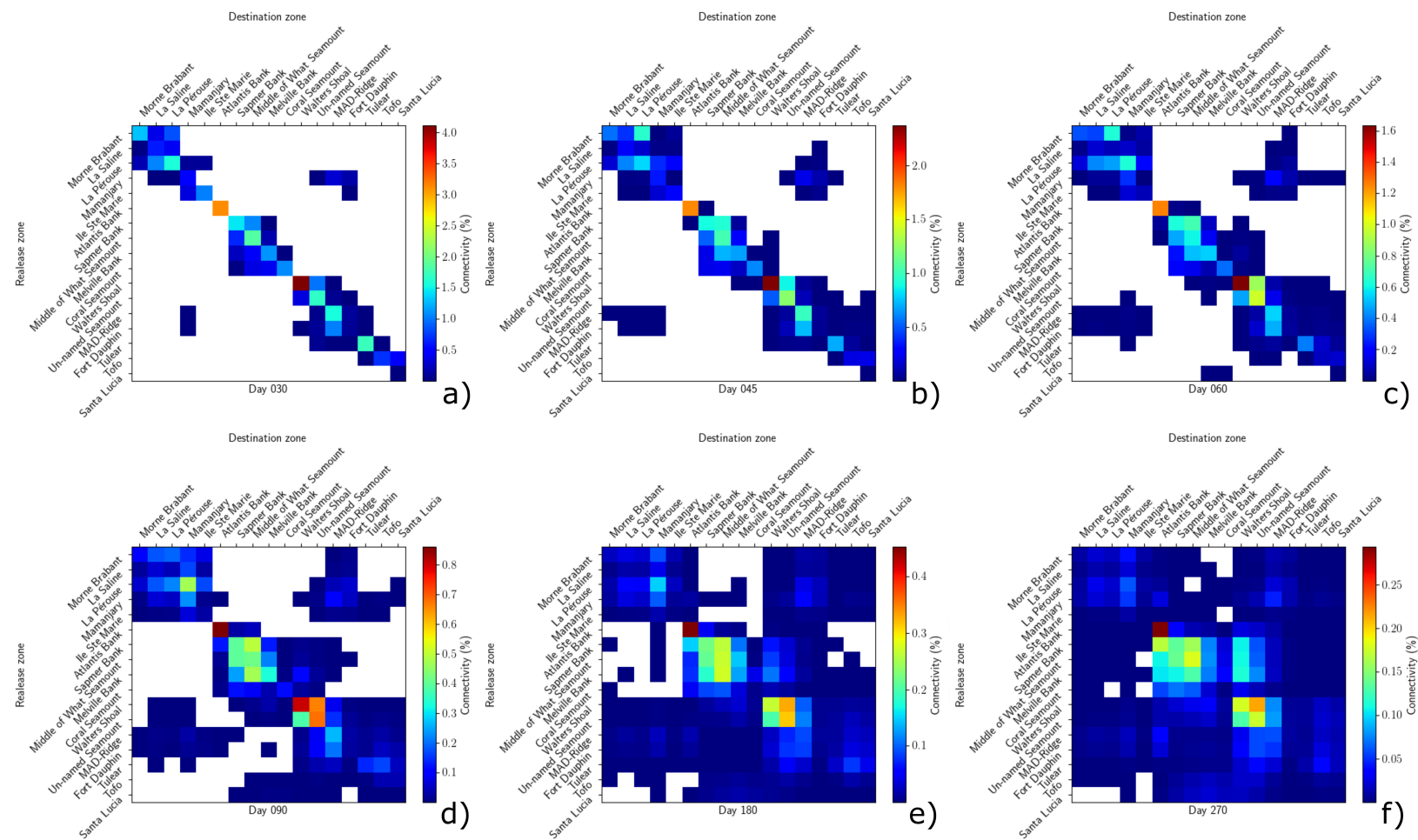

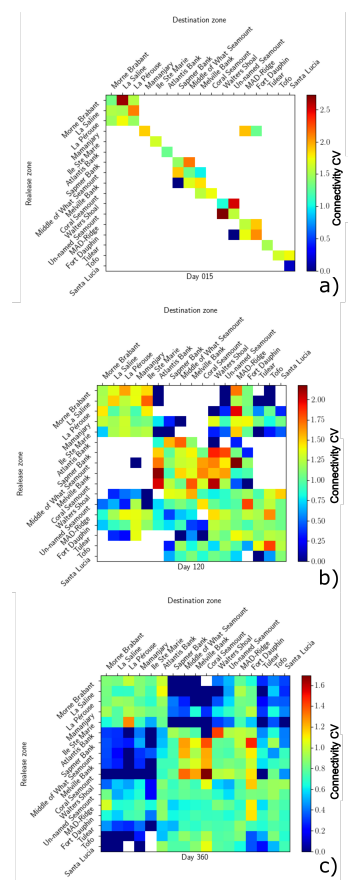

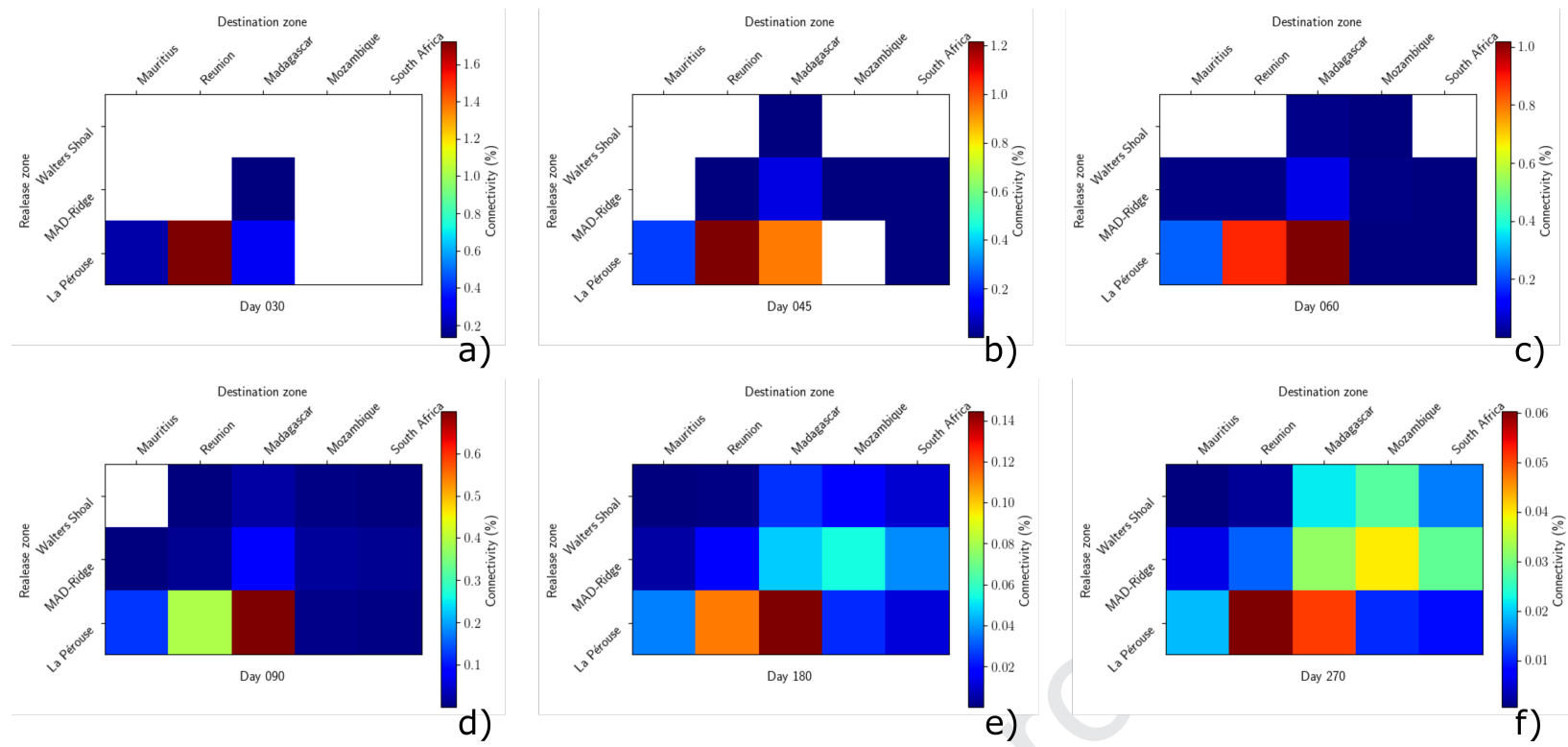

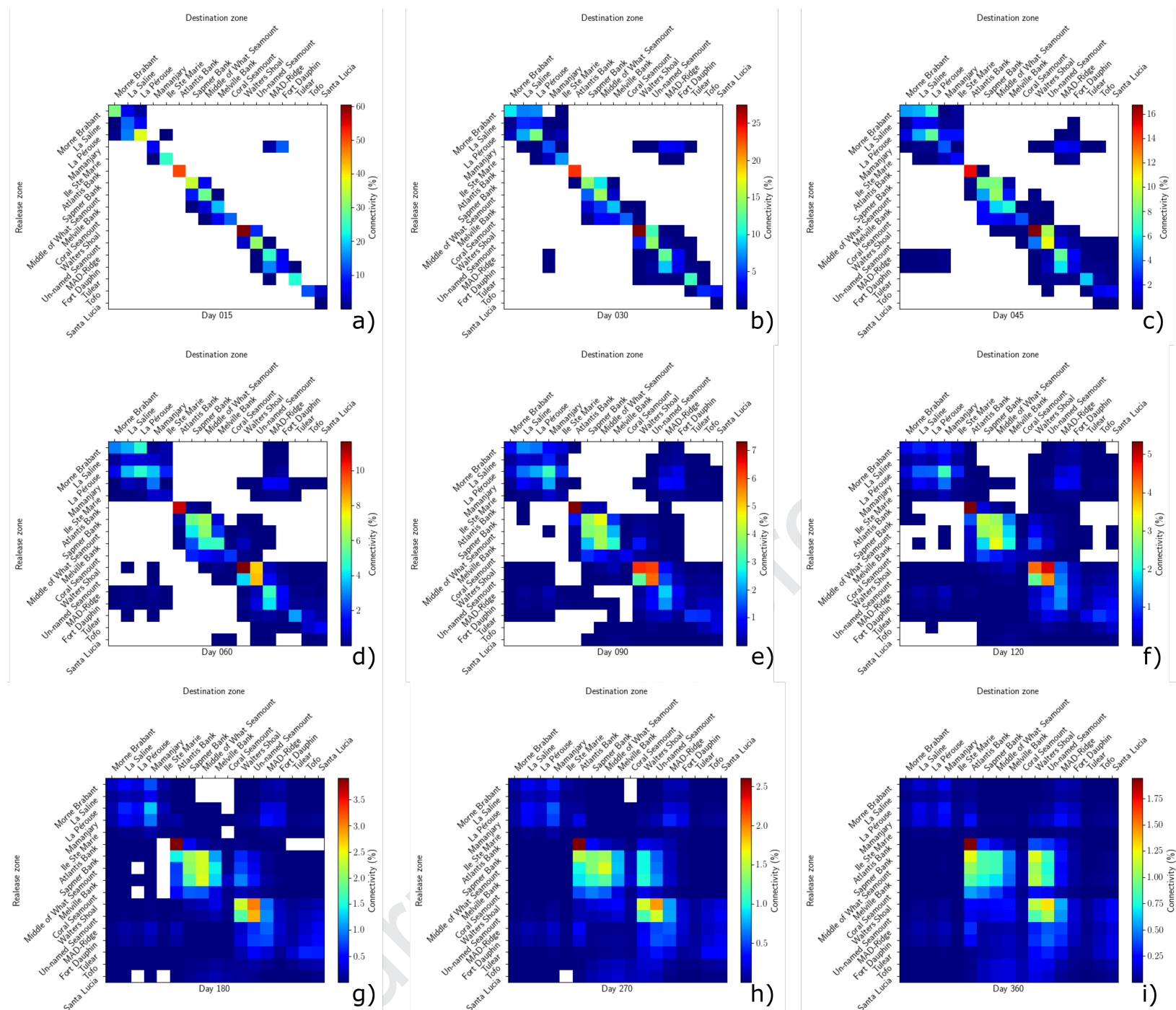


\section{Declaration of interests}

$\bigotimes$ The authors declare that they have no known competing financial interests or personal relationships that could have appeared to influence the work reported in this paper.

$\square$ The authors declare the following financial interests/personal relationships which may be considered as potential competing interests: 